\title{
Long-term c-Kit overexpression in beta cells compromises their function in ageing mice
}

\author{
Amanda Oakie $^{1,2} \cdot$ Zhi-Chao Feng $^{1} \cdot$ Jinming $\mathrm{Li}^{1,3} \cdot$ Jenna Silverstein ${ }^{1} \cdot$ Siu-Pok Yee ${ }^{4,5} \cdot$ Rennian Wang $^{1,3,6}$ (D
}

Received: 5 December 2018 / Accepted: 4 April 2019 / Published online: 1 June 2019

(C) Springer-Verlag GmbH Germany, part of Springer Nature 2019

\begin{abstract}
Aims/hypothesis c-Kit signalling regulates intracellular pathways that enhance beta cell proliferation, insulin secretion and islet vascularisation in mice up to 28 weeks of age and on short-term high-fat diet. However, long-term c-Kit activation in ageing mouse islets has yet to be examined. This study utilises beta cell-specific c-Kit-overexpressing transgenic (c-Kit $\beta$ Tg) ageing mice ( $\sim 60$ weeks) to determine the effect of its activation on beta cell dysfunction and insulin secretion.

Methods Wild-type and c-Kit $\beta$ Tg mice, aged 60 weeks, were examined using metabolic tests to determine glucose tolerance and insulin secretion. Pancreas histology and proteins in isolated islets were examined to determine the expression of beta cell transcription factors, proliferation and intracellular signalling. To determine the role of insulin receptor signalling in ageing cKit $\beta$ Tg mice, we generated beta cell-specific inducible insulin receptor knockout in ageing c-Kit $\beta$ Tg mice (c-Kit $\beta$ Tg; $\beta$ IRKO mice) and examined the ageing mice for glucose tolerance and islet histology.

Results Ageing c-Kit $\beta$ Tg mice progressively developed glucose intolerance, compared with age-matched wild-type littermates, due to impaired insulin secretion. Increased beta cell mass, proliferation and nuclear forkhead box transcription factor $\mathrm{O} 1$ (FOXO1) expression and reduced exocytotic protein levels were detected in ageing c-Kit $\beta$ Tg mouse islets. Protein analyses of isolated islets showed increased insulin receptor, phosphorylated IRS-1 ${ }^{\text {Ser612 }}$ and cleaved poly(ADP-ribose) polymerase levels in ageing c-Kit $\beta$ Tg mice. Ageing c-Kit $\beta$ Tg mouse islets treated ex vivo with insulin demonstrated reduced Akt phosphorylation, indicating that prolonged c-Kit induced beta cell insulin insensitivity. Ageing c-Kit $\beta$ Tg; $\beta$ IRKO mice displayed improved glucose tolerance and beta cell function compared with ageing c-Kit $\beta$ Tg mice.

Conclusions/interpretation These findings indicate that long-term c-Kit overexpression in beta cells has a negative impact on insulin exocytosis and that temporally dependent regulation of c-Kit-insulin receptor signalling is important for optimal beta cell function.
\end{abstract}

Keywords c-Kit · Insulin receptor - IRS-1 serine phosphorylation - MIP-CreER mouse model · Receptor tyrosine kinase · SNARE · Tamoxifen-induced

Amanda Oakie and Zhi-Chao Feng contributed equally to this work.

Electronic supplementary material The online version of this article (https://doi.org/10.1007/s00125-019-4890-5) contains peer-reviewed but unedited supplementary material, which is available to authorised users.

Rennian Wang

rwang@uwo.ca

1 Children's Health Research Institute, University of Western Ontario, Victoria Research Laboratories, Room A5-140, 800 Commissioners Road East, London, ON N6C 2V5, Canada

2 Department of Pathology and Laboratory Medicine, University of Western Ontario, London, ON, Canada
3 Department of Physiology and Pharmacology, University of Western Ontario, London, ON, Canada

4 Department of Cell Biology, University of Connecticut Health Center, Farmington, CT, USA

5 Department of Genetics and Genome Sciences, University of Connecticut Health Center, Farmington, CT, USA

6 Department of Medicine, University of Western Ontario, London, ON, Canada 


\section{Research in context}

\section{What is already known about this subject?}

- c-Kit activity is required in mature beta cells to maintain islet function and normoglycaemia. Heterozygous mice with an intracellular point mutation that disrupts c-Kit activation display glucose intolerance and reduced glucosestimulated insulin secretion

- Overexpression of c-Kit by beta cells enhances insulin release and islet vascularisation, improves beta cell survival rate and proliferation and upregulates insulin receptor expression

- c-Kit overexpression during long-term metabolic challenges, as seen during high-fat diet feeding, detrimentally affects islet function by inducing islet inflammation and apoptosis

\section{What is the key question?}

- What are the effects of long-term beta cell c-Kit overexpression on beta cell function in ageing (60 weeks old) mice?

\section{What are the new findings?}

- Overexpression of c-Kit in beta cells during ageing resulted in increased beta cell mass and proliferation but impaired glucose tolerance and insulin release compared with age-matched wild-type mice

- Ageing c-Kit-overexpressing beta cells displayed a reduction in exocytotic proteins, changes in intracellular signalling and loss of insulin sensitivity through the insulin receptor-IRS-1 axis

- Reducing beta cell insulin receptor expression in ageing c-Kit-overexpressing mice partially restored glucose tolerance and beta cell function

\section{How might this impact on clinical practice in the foreseeable future?}

- Therapies that regulate $\mathrm{c}-\mathrm{Kit}$ signalling in beta cells with the aim of improving beta cell function will need to take the duration of administration into consideration

\begin{tabular}{|c|c|}
\hline \multicolumn{2}{|l|}{ Abbreviations } \\
\hline $\mathrm{c}-\mathrm{Kit} \beta \mathrm{Tg}$ & $\begin{array}{l}\text { Beta cell-specific c-Kit- } \\
\text { overexpressing transgenic }\end{array}$ \\
\hline c-Kit $\beta$ Tg; $\beta$ IRKO & $\begin{array}{l}\text { Beta cell-specific inducible } \\
\text { insulin receptor knockout in } \\
\text { ageing c-Kit } \beta T g\end{array}$ \\
\hline ERK & Extracellular signal-regulated kinase \\
\hline FOXO1 & Forkhead box transcription factor $\mathrm{O} 1$ \\
\hline GSIS & Glucose-stimulated insulin secretion \\
\hline MafA & $\begin{array}{l}\text { v-maf musculoaponeurotic } \\
\text { fibrosarcoma oncogene family } \\
\text { protein A }\end{array}$ \\
\hline MUNC18-1 & Mammalian homologue of Unc18-1 \\
\hline NKX6.1 & NK-homeodomain factor 6.1 \\
\hline PARP & Poly (ADP-ribose) polymerase \\
\hline PDX-1 & Pancreatic and duodenal homeobox-1 \\
\hline PI3K & Phosphatidylinositol 3-kinase \\
\hline SNAP25 & $\begin{array}{l}\text { Synaptosome-associated protein } \\
\text { of } 25 \mathrm{kDa}\end{array}$ \\
\hline SNARE & $\begin{array}{l}\text { Soluble } N \text {-ethylmaleimide-sensitive } \\
\text { factor attachment protein receptor }\end{array}$ \\
\hline VAMP2 & Vesicle-associated membrane protein \\
\hline VEGF & Vascular endothelial growth factor \\
\hline
\end{tabular}

\section{Introduction}

The development of beta cell dysfunction produces abnormal blood glucose levels and progressively leads to diabetes mellitus, highlighting a need for research that focuses on restoring the functional capacity of beta cells to control hyperglycaemia in affected individuals. The receptor tyrosine kinase c-Kit is present in the pancreas during development and in the mature beta cell population [1-3]. Beta cellspecific c-Kit signalling maintains the development of beta cell mass in mice via activation of the phosphatidylinositol 3-kinase (PI3K)-Akt pathway, which enhances insulin release [4-6]. c-Kit activation also protects against Fas receptor-induced apoptosis and upregulates vascular endothelial growth factor (VEGF)-A production to promote islet vascularisation $[7,8]$. However, the introduction of a longterm high-fat diet to beta cell-specific c-Kit-overexpressing transgenic (c-Kit $\beta \mathrm{Tg}$ ) mice was reported to produce vasculature dilation and subsequent infiltration of inflammatory markers, leading to beta cell failure and islet apoptosis [7]. Therefore, it is essential to regulate c-Kit activation in beta cells to ensure that prolonged receptor signalling does not impede optimal beta cell function. 
The physiological changes that occur during ageing of islets are associated with the development of abnormal beta cell function and include reduced insulin secretion and decreased Ins1/Ins 2 and Glut-2 (also known as Slc2a2) mRNA expression [9, 10]. Ageing beta cells display increased gene expression levels of $p 16^{I N K 4 a}$ (also known as Cdkn2a) and exhibit lower cellular replication when compared with young beta cells but select studies have found that they retain their potential to proliferate as a response to beta cell damage [11-16]. Ageing islets are also susceptible to increased beta cell apoptosis through the Fas receptor and reduced pancreatic and duodenal homeobox-1 (PDX-1) expression and insulin release [17], indicating that there is an age-dependent component to beta cell dysfunction. However, the induction of beta cell senescence in ageing islets has also been reported to enhance insulin secretion [18], emphasising that the effects of islet ageing are not well established.

Signalling through c-Kit activity has been found to improve many of the factors associated with age-dependent decline in beta cell function $[4,8]$ but the effects of its long-term overexpression in beta cells is currently not known. This study employs the c-Kit $\beta$ Tg mouse model [4] to determine the effects of chronic c-Kit overexpression in ageing ( $\sim 60$ weeks) mice towards maintaining glucose metabolism, beta cell mass and insulin release. We also generated a beta cell-specific inducible insulin receptor knockout in ageing c-Kit $\beta \mathrm{Tg}$ (c$\mathrm{Kit} \beta \mathrm{Tg}$; $\beta$ IRKO) mouse line in order to determine the role of insulin receptor signalling in ageing c-Kit $\beta \mathrm{Tg}$ mice.

\section{Methods}

\section{Generation of c-Kit $\beta T g$ and c-Kit $\beta$ Tg; $\beta I R K O$ mouse models}

Beta cell-specific c-Kit overexpression at 60 weeks of age c$\mathrm{Kit} \beta \mathrm{Tg}$ mice were obtained by pronuclear microinjection of a transgene, with the rat insulin promoter driving expression of human $c$-KIT (also known as KIT) cDNA, directly into C57BL/6J one-cell mouse embryos and confirmed using genotyping measures (ESM Table 1) as previously described [4]. Male c-Kit $\beta$ Tg mice and their age-matched wild-type littermates were housed in the same AN75 mouse cage (Ancare, Bellmore, NY, USA; maximum of five mice per cage) in a pathogen-free facility. Mice had free access to a normal diet (Harlan Teklad, Indianapolis, IN, USA) and were exposed to a $12 \mathrm{~h}$ light-dark cycle throughout the study. Weekly health checks were performed on all mice and any that developed health concerns were excluded from the study. Experimental analyses were performed in mice killed at 60 weeks of age.
Inducible beta cell-specific insulin receptor knockout in ageing c-Kit $\beta$ Tg mice To generate the c-Kit $\beta$ Tg; $\beta$ IRKO mouse model, Tg (Ins 1-Cre/ERT) ${ }^{1 \text { Lphi }}$ mice (MIP-CreERT) were obtained from L. Philipson (University of Chicago, Chicago, IL, USA) and crossed with B6.129S4(FVB)-Insr $r^{t m 1 K h n} / \mathrm{J}$ mice $\left(I R^{\mathrm{fl} / \mathrm{fl}}\right.$; note that $I R$ is also known as Insr) from Jackson Laboratories (stock no. 006955) to create mice with a tamoxifen-inducible Cre recombinase knockout of beta cell insulin receptor (MIP-CreER:IR ${ }^{\mathrm{fl} /+}$ ) [19]. c-Kit $\beta$ Tg mice were crossed to generate four separate experimental groups determined by genotyping (ESM Table 1): control (WT;MIP$C r e E R^{+} ; I R^{+/+}$or WT;MIP-CreER $\left.R^{-} I R^{\mathrm{fl} / \mathrm{fl}}\right) ; \mathrm{c}-\mathrm{Kit} \beta \mathrm{Tg}(c-$ Kit $\left.\beta T g ; M I P-C r e E R^{+} ; I^{+/+}\right) ;$c-Kit $\beta$ Tg; $\beta$ IRKO (cKit $\beta T g ; M I P-C r e E R^{+} ; I R^{\mathrm{fl} / \mathrm{fl}}$ ) and MIP- $\beta$ IRKO (WT;MIP$\left.\mathrm{CreER}^{+} ; I R^{\mathrm{fl} / \mathrm{fl}}\right)$. Tamoxifen was administered via oral gavage (4 mg/20 g body weight) to male mice from all groups at 40 weeks of age for three consecutive days to induce insulin receptor knockout [20]. All animal work was conducted based on an approved protocol by the University of Western Ontario Animal User Subcommittee in accordance with the Canadian Council of Animal Care guidelines.

\section{Metabolic studies in experimental mouse models}

Body weight and fasting (overnight, $16 \mathrm{~h}$ ) blood glucose levels were measured in mice at 40 and 60 weeks of age, with previous data from 8- and 28-week-old mice used as a comparison $[4,7]$. Food intake of ageing ( 60 weeks old) wild-type and c-Kit $\beta$ Tg mice was monitored daily over a $72 \mathrm{~h}$ period. Intraperitoneal glucose and insulin tolerance tests (IPGTT and IPITT, respectively) were performed following the i.p. administration of glucose (Sigma-Aldrich, Oakville, ON, Canada) at a dose of $2 \mathrm{mg} / \mathrm{g}$ body weight and insulin (Humulin; Eli Lilly, Toronto, ON, Canada) at $1 \mathrm{U} / \mathrm{kg}$ body weight, respectively [4]. Blood glucose levels were measured before $(0 \mathrm{~min})$ and after injection $(15,30,60,90$, and $120 \mathrm{~min})$ and the area under the curve (AUC) was used to quantify responsiveness [4, 7].

For determination of in vivo glucose-stimulated insulin secretion (GSIS), blood samples were collected following $16 \mathrm{~h}$ fasting (0 min) and at 5 and $35 \mathrm{~min}$ after i.p. injection of glucose. For determination of ex vivo GSIS, ten islets isolated from wild-type and $\mathrm{c}-\mathrm{Kit} \beta \mathrm{Tg}$ mouse pancreases were randomly hand-picked and recovered overnight in RPMI-1640 medium plus $10 \%$ FBS. Islets were sequentially treated for $1 \mathrm{~h}$ in low $(2.2 \mathrm{mmol} /$ 1) and high glucose (22 mmol/l) with RPMI 1640 plus $0.5 \%$ BSA media [7]. Insulin secretion and islet insulin content were analysed using a mouse ultrasensitive insulin ELISA kit (ALPCO, Salem, NH, USA) [4]. Total insulin content was measured and normalised to the total islet protein content $(\mu \mathrm{g} / \mathrm{mg})$. All littermates within a cage had metabolic experiments performed at the same time and under identical conditions. 


\section{Ex vivo islet culture with insulin}

Islets isolated from ageing wild-type and c-Kit $\beta \mathrm{Tg}$ mice were separated into two individual wells on a plate and incubated in RPMI-1640 plus $1 \%$ BSA media for $3 \mathrm{~h}$, followed by incubation for $24 \mathrm{~h}$ with or without $2 \mathrm{nmol} / \mathrm{l}$ insulin. All islets were harvested and lysed for western blot protein analyses. Mice from multiple litter sets, with no blinding for genotype, were used for this experiment.

\section{Histological staining and morphometric analyses}

Pancreases from ageing mice were fixed in $4 \%$ paraformaldehyde, embedded in paraffin and sectioned at $4 \mu \mathrm{m}$. Histological analysis was completed by staining with primary antibodies diluted in DakoCytomation antibody diluent (Dako Canada, Burlington, ON, Canada) at the reported dilution (ESM Table 2). Fluorescein isothiocyanate (FITC) and tetramethyl rhodamine isothiocyanate (TRITC) immuofluorescence secondary antibodies (Jackson Immunoresearch, West Grove, PA, USA) were used at a 1:50 dilution. Slide washes were completed using $1 \times$ phosphate buffered saline (PBS). The Zymed Histostain Plus IHC Kit and aminoethyl carbazole (AEC) substrate kit (Invitrogen, Burlington, ON, Canada) were used as per the manufacturer's instructions for immunohistochemistry detection. Citrate $(\mathrm{pH}$ 6.0) or Tris-EDTA (pH 9.0) antigen retrieval solutions were used when required. Images were captured and quantified using Image Pro Plus software, version 7.0.1 (MediaCybernetics, Rockville, MD, USA). Antibodies were validated by utilizing negative control slides (primary or secondary antibody excluded). Representative immunofluorescence images were captured using Nikon Eclipse Ti2 confocal microscope (Nikon, Melville, NY, USA). Quantifications of islet density, alpha and beta cell mass and average beta cell size were performed as previously described $[5,8]$. Beta cell proliferation and expression of transcription factors and soluble $N$-ethylmaleimide-sensitive factor attachment protein receptor (SNARE) were identified by double immunofluorescence staining and quantification from at least ten random islets per pancreatic section [5, 8]. Islet capillary density, area per islet and average islet diameter were measured [7]. Histological samples from multiple litter sets were analysed and blinding for the genotype of pancreas sections was performed.

\section{Protein quantification and western blot analysis}

Equal amounts of protein $(20 \mu \mathrm{g})$ prepared from isolated islets of ageing wild-type and c-Kit $\beta \mathrm{Tg}$ mice were fractionated by SDS-PAGE (5-12\%). The fractionated protein was transferred onto nitrocellulose membranes. Primary (ESM Table 2) and horseradish peroxidase-conjugated secondary antibodies (Cell
Signaling Technology, Boston, MA, USA) were used for protein detection and western blot ECL substrate (Perkin Elmer, Waltham, MA, USA) was used for band visualisation. All membranes were imaged using the Versadoc system in conjunction with Quantity One software, version 4.6.9 (Bio-Rad Laboratories, Hercules, CA, USA). Signal intensities were densitometrically quantified by Image Lab software, version 5.2 (Bio-Rad Laboratories, Hercules, CA, USA). Data were normalised to total or loading controls [5, 8]. Islet samples were collected from multiple litter sets and the analysed data did not come exclusively from one cage of mice. Samples were excluded from analyses if protein was not detected.

\section{Statistical analysis}

Data are expressed as mean \pm SEM. Statistical significance was analysed using an unpaired Student's $t$ test if comparing only two groups, or one-way ANOVA with Tukey's post hoc test when analysing more than two groups on GraphPad Prism, version 5.0 (GraphPad Software, San Diego, CA, USA). Differences were considered to be statistically significant when $p<0.05$.

\section{Results}

\section{Chronic c-Kit overexpression led to impaired glucose metabolism in ageing c-Kit $\beta \mathrm{Tg}$ mice}

Unchanged body weight measurements when comparing young wild-type with c-Kit $\beta \mathrm{Tg}$ mice were observed in previous studies $[4,7]$. During the current study, c-Kit $\beta T g$ and wild-type mice had similar body weights at 40 weeks of age but ageing c-Kit $\beta \mathrm{Tg}$ mice ( 60 weeks old) exhibited increased body weight compared with wild-type littermates (Fig. 1a). Previous reports found improved fasting blood glucose in young c-Kit $\beta \mathrm{Tg}$ mice $[4,7]$, yet the current study demonstrated blood glucose levels were similar in wild-type and c$\mathrm{Kit} \beta \mathrm{Tg}$ mice at 40 weeks of age and significantly elevated levels in c-Kit $\beta$ Tg mice at 60 weeks (Fig. 1b). Analysis of pancreatic and fat pad mass in 60-week-old mice revealed no significant differences between wild-type and c-Kit $\beta \mathrm{Tg}$ mice (ESM Fig. 1a,b). The average $24 \mathrm{~h}$ food intake over a 3 day period did not differ between the two groups (ESM Fig. 1c).

Although improved glucose tolerance was previously reported in young c-Kit $\beta$ Tg mice [4, 7], 60-week-old c-Kit $\beta T g$ mice demonstrated impaired glucose tolerance, compared with their wild-type counterparts, and plasma glucose levels had not returned to basal levels at 120 min (Fig. 1c). The IPITT revealed similar insulin sensitivity between wild-type and c-Kit $\beta$ Tg mice despite their extended age (Fig. 1d), indicating that the poor glucose tolerance observed in ageing cKit $\beta$ Tg mice was due to beta cell defects. Ex vivo GSIS 
demonstrated similar insulin release at $2.2 \mathrm{mmol} / \mathrm{l}$ of glucose stimulation; however, lower insulin secretion in c-Kit $\beta \mathrm{Tg}$ mouse islets was found when islets were incubated in $22 \mathrm{mmol} / \mathrm{l}$ glucose (Fig. 1e). There was no difference in the insulin content of islets isolated from ageing c-Kit $\beta T$ g mice vs wild-type mice (Fig. 1f).

\section{Chronic c-Kit overexpression increased beta cell mass, beta cell proliferation and nuclear forkhead box transcription factor 01 localisation in ageing c-Kit $\beta T g$ mice}

Histological analyses of pancreases from c-Kit $\beta \mathrm{Tg}$ mice showed an increase in beta cell mass, with no discernible changes in islet density or alpha cell mass (Fig. 2a,b,d). The increased beta cell mass in ageing c-Kit $\beta T$ g mice (Fig. 2c) was not due to a change in beta cell size (Fig. 2e) but was caused by higher beta cell proliferation, as shown using Ki67 co-staining (Fig. 2f). When analysing transcription factors in beta cell nuclei that control beta cell function and insulin secretion, it was found that nuclear PDX-1 expression was similar between the ageing groups (Fig. $2 \mathrm{~g}$,h). In contrast, islets from ageing c-Kit $\beta T g$ mice displayed a higher degree of forkhead box transcription factor O1 (FOXO1) nuclear shuttling (Fig. 2g,i). No changes were found between mouse groups for NK-homeodomain factor 6.1 (NKX6.1) and vmaf musculoaponeurotic fibrosarcoma oncogene family protein A (MafA) nuclear expression or GLUT2 staining on beta cell membranes (ESM Fig. 2). Vascularisation was also analysed and compared between ageing wild-type and c-
Fig. 1 Ageing c-Kit $\beta$ Tg mice displayed glucose intolerance because of reduced insulin release. $(\mathbf{a}, \mathbf{b})$ Body weight measurements in wild-type (WT) and c-Kit $\beta$ Tg mice at age 40 weeks ( $n=13 \mathrm{WT} ; n=30 \mathrm{c}-$ $\mathrm{Kit} \beta \mathrm{Tg})$ and 60 weeks $(n=20$ WT; $n=22$ c-Kit $\beta \mathrm{Tg}$ ) (a), and overnight $(\sim 16 \mathrm{~h})$ fasting blood glucose at age 40 weeks ( $n=13$ WT; $n=30 \mathrm{c}-\mathrm{Kit} \beta \mathrm{Tg}$ ) and 60 weeks ( $n=15 \mathrm{WT} ; n=20 \mathrm{c}-$ $\mathrm{Kit} \beta \mathrm{Tg}$ ) (b), compared with mice previously analysed at 8 and 28 weeks of age $[4,7]$. (c, d) IPGTT with AUC (c) and IPITT with AUC (d) from 60-week-old WT and c-Kit $\beta$ Tg mice $(n=13 \mathrm{WT}$ and $n=19 \mathrm{c}-\mathrm{Kit} \beta \mathrm{Tg}$ mice/group for IPGTT; $n=10$ WT and $n=13 \mathrm{c}$ $\mathrm{Kit} \beta \mathrm{Tg}$ mice/group for IPITT).

(e) Ex vivo GSIS from ten isolated islets per biological replicate of 60-week-old WT and c-Kit $\beta T$ g mice exposed to low glucose $(2.2 \mathrm{mmol} / \mathrm{l})$ and high glucose $(22 \mathrm{mmol} / \mathrm{l})(n=5$ islet isolations/group). (f) Total insulin content from isolated islets of 60 week-old WT and c-Kit $\beta$ Tg mice ( $n=4$ islet isolations/group). Data are expressed as mean \pm SEM. ${ }^{*} p<0.05$ and $* * p<0.01$ (unpaired Student's $t$ test)
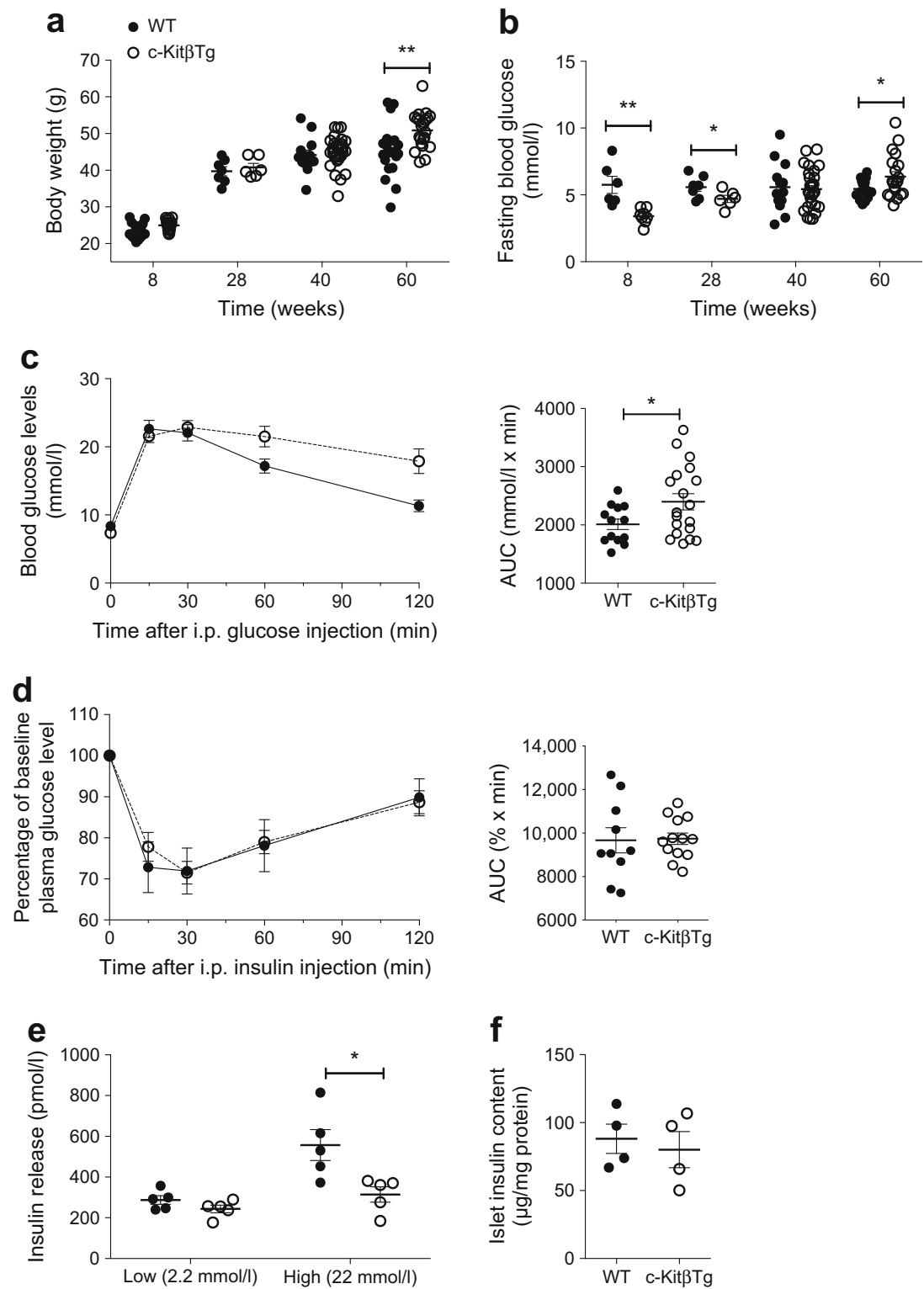
Fig. 2 Histological analysis of ageing c-Kit $\beta$ Tg mouse pancreases demonstrated increased beta cell mass, proliferation and FOXO1 nuclear localisation. (a) Representative immunofluorescence image of islet morphology in 60-week-old wild-type (WT) and c-Kit $\beta \mathrm{Tg}$ mouse pancreases, detected by insulin staining (red). DAPI was used to counterstain nuclei (blue). Scale bars, $200 \mu \mathrm{m}$. (b-e)

Measurements of islet density (b), beta cell mass (c), alpha cell mass (d) and individual beta cell size (e) in 60-week-old WT and cKit $\beta \operatorname{Tg}$ mice ( $n=5$ pancreases/ group). (f) Proliferation of beta cells quantified using cell cycle marker Ki67 co-localisation with insulin-positive cells ( $n=4$ pancreases/group). (g) Representative double immunofluorescence image of PDX-1 or FOXO1 (both green) co-localised with insulin-positive (red) cells. Nuclei are stained with DAPI (blue). Scale bars, $50 \mu \mathrm{m}$. (h, i) Quantification of nuclear PDX-1 (h; $n=5$ WT and $n=6$ cKit $\beta$ Tg mouse pancreases/group) and FOXO1 (i; $n=4$ WT and $n=5$ c-Kit $\beta T$ g mouse pancreases/ group) in insulin-positive cells of ageing mice. Data are expressed as mean \pm SEM. $* p<0.05$ and ** $p<0.01$ (unpaired Student's $t$ test). Ins, insulin a
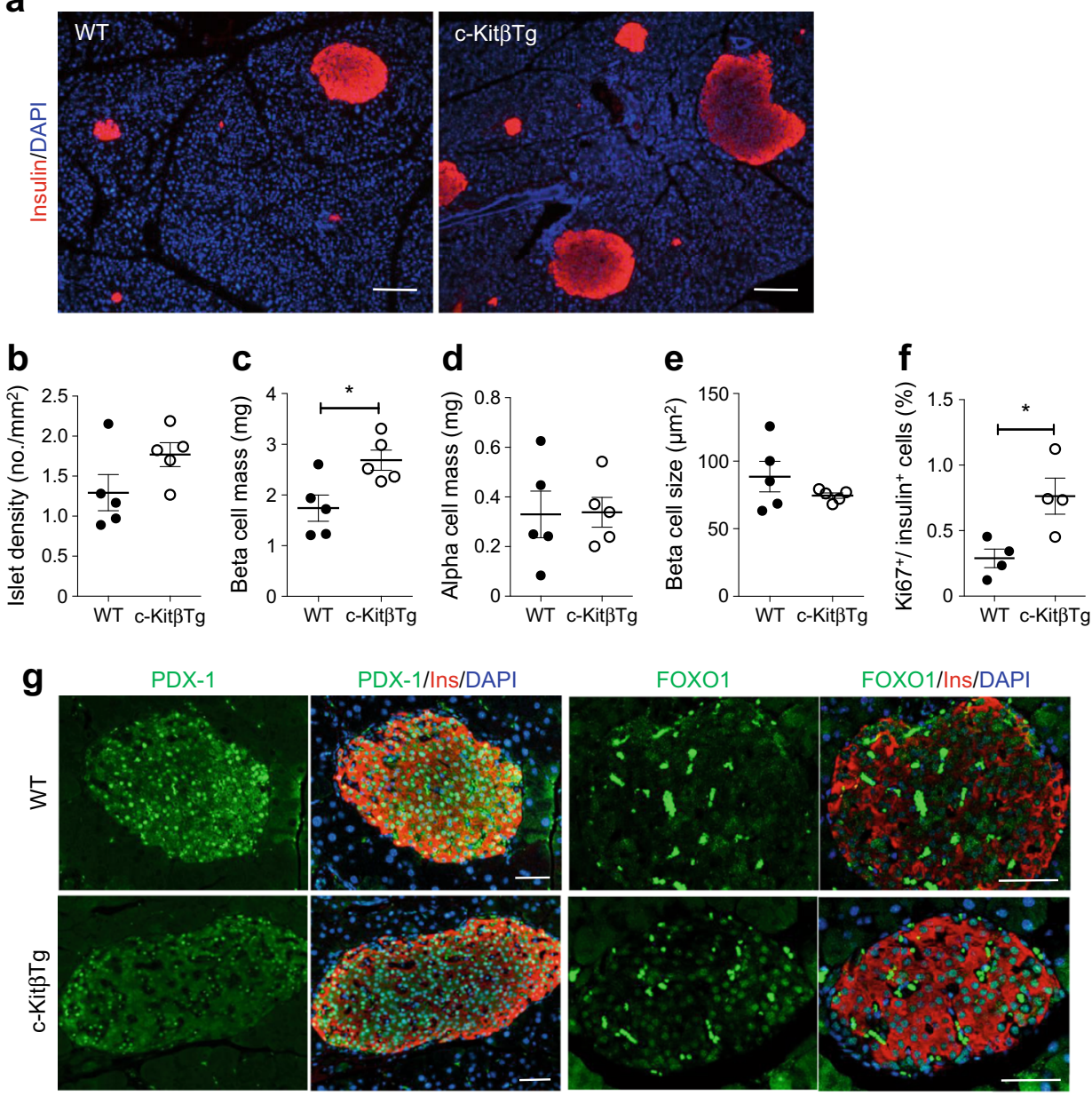

PDX-1/Ins/DAPI
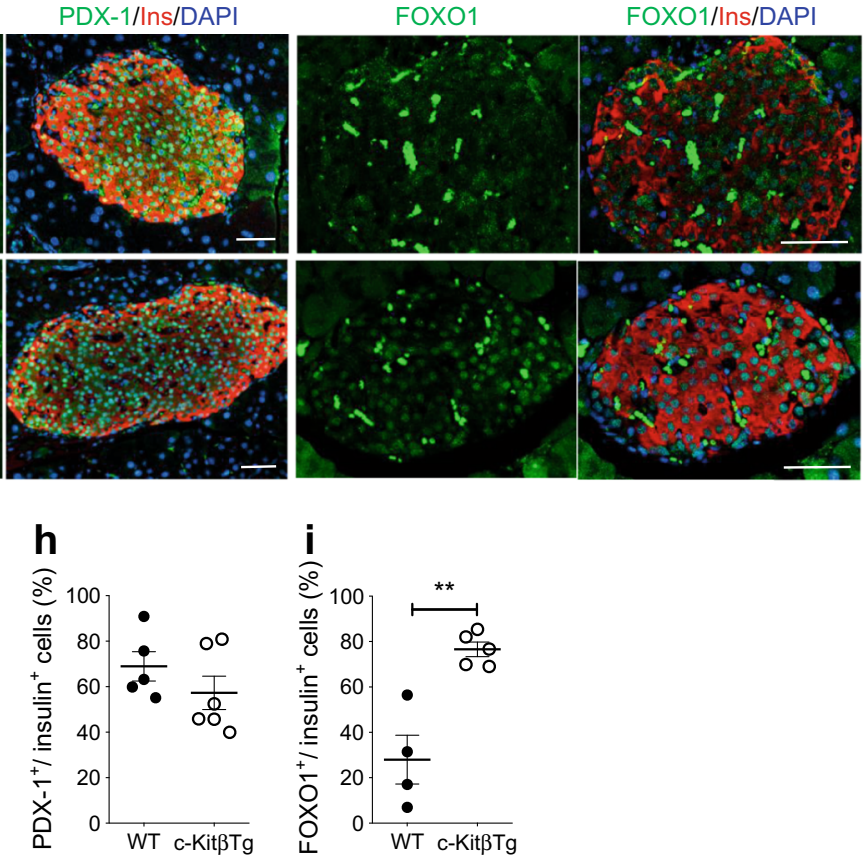

Kit $\beta T g$ mouse islets; the islets from the two groups displayed similar levels of capillary density, area and diameter (ESM Fig. 3).

\section{Chronic c-Kit overexpression resulted in reduced exocytosis-regulating SNARE proteins in ageing c-Kit $\beta T g$ mouse islets}

The SNARE complex, required for insulin vesicle tethering and fusion to the membrane, was examined to determine its expression in ageing islets. Significantly reduced levels of syntaxin 1A (Fig. 3a,b) and its associated chaperone protein mammalian homologue of Unc18-1 (MUNC18-1) (Fig. $3 \mathrm{c}, \mathrm{d})$ were detected in islets isolated from $\mathrm{c}-\mathrm{Kit} \beta \mathrm{Tg}$ mice. Histological review revealed no difference in synaptosomeassociated protein of $25 \mathrm{kDa}$ (SNAP25; part of the SNARE tethering complex) staining between wild-type and cKit $\beta$ Tg mice (Fig. 3e) but relatively low staining signals for vesicle-associated membrane protein 2 (VAMP2; found on the insulin vesicle membrane) in ageing c-Kit $\beta \mathrm{Tg}$ mouse islets (Fig. 3e). These data imply that chronic c-Kit overexpression impairs insulin release in ageing $\mathrm{c}-\mathrm{Kit} \beta \mathrm{Tg}$ mouse beta cells mediated by reduced expression of SNARE proteins. 


\section{Chronic c-Kit overexpression increased insulin

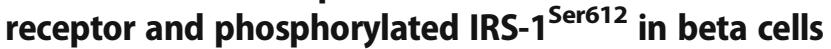 and resulted in an impaired response to insulin stimulation in ageing c-Kit $\beta \mathrm{Tg}$ mouse islets}

Although young c-Kit $\beta$ Tg mice (8-28 weeks of age) demonstrated increased insulin release and enhanced insulin receptor-pIRS $1 / 2^{\text {Tyr612 }}-\mathrm{Akt}^{\text {Ser473 }}$ signalling [4, 7], ageing c-Kit $\beta \mathrm{Tg}$ mouse islets showed increased expression levels of insulin receptor and phosphorylated IRS-1 ${ }^{\text {Ser612 }}$ (Fig. 4a). Immunofluorescence analysis for total IRS-1 in ageing mouse pancreases also demonstrated significantly reduced levels in c-Kit $\beta \mathrm{Tg}$ vs wild-type mouse beta cells (Fig. 4b), yet no change in total IRS-2 staining was observed between mouse groups (data not shown). The higher level of phosphorylated $\mathrm{Akt}^{\mathrm{Ser} 473}$ observed in young c-Kit $\beta \mathrm{Tg}$ mice [4] was abolished in the ageing c-Kit $\beta$ Tg cohort and a statistically non-significant increase in signalling through phosphorylated extracellular signal-regulated kinase (ERK) 1/2 was found in ageing c-Kit $\beta$ Tg mouse islets (Fig. 4c). The apoptotic markers cleaved poly(ADP-ribose) polymerase (PARP) and cleaved caspase 3 were increased in ageing c-Kit $\beta \mathrm{Tg}$ mouse islets (Fig. 4c and ESM Fig. 4).
Fig. 3 The expression of exocytotic SNARE proteins in ageing c-Kit $\beta$ Tg mouse islets. (a, c) Representative western blot images and densitometry analysis of syntaxin 1A (a) and MUNC18 1 (c) bands in ageing mouse islets ( $n=4$ isolated islets/group). (b, d, e) Representative immunofluorescence images of syntaxin 1A (b), MUNC18-1 (d) and SNAP25 and VAMP2 (e) in ageing wild-type (WT) and cKit $\beta$ Tg mouse islets. SNARE proteins are stained green, insulinpositive cells are stained red. Nuclei are stained with DAPI (blue). Scale bars, $50 \mu \mathrm{m}$. Data are expressed as mean \pm SEM. $* p<0.05$ and $* * p<0.01$ (unpaired Student's $t$ test). Ins, insulin a
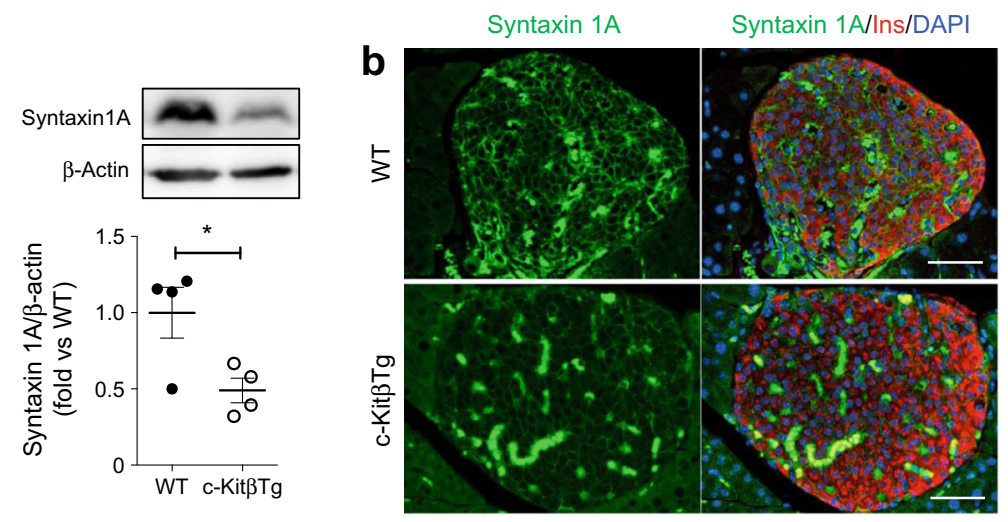

C

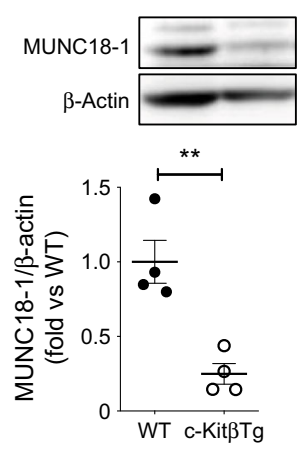

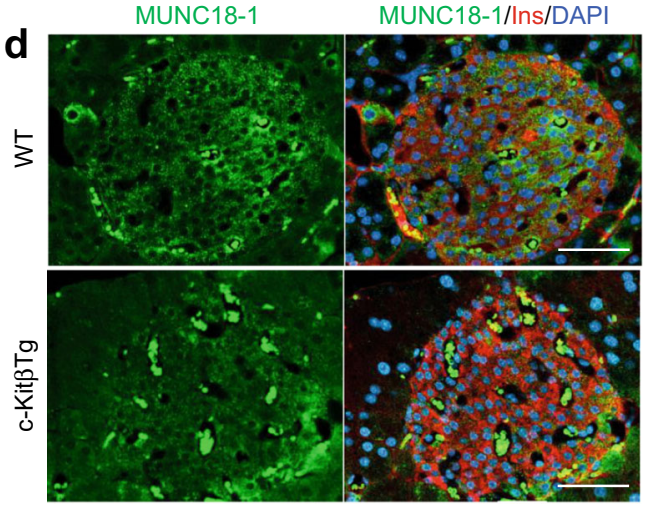

e

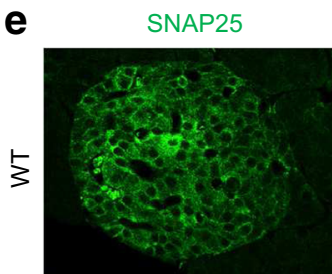
SNAP25/Ins/DAP
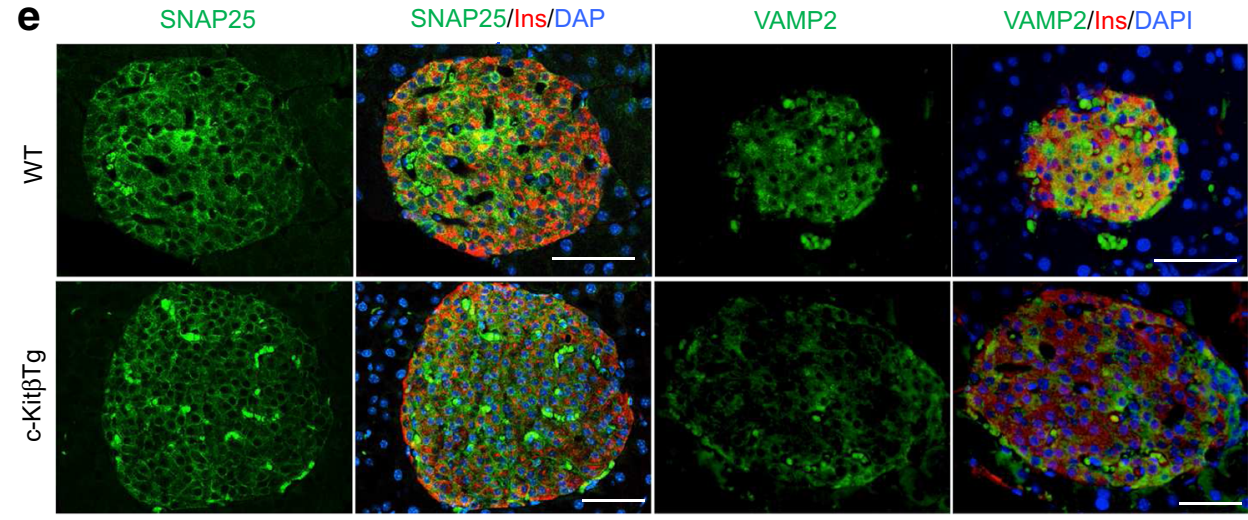
Fig. 4 Increased insulin receptor (IR), phosphorylated IRS-1 ${ }^{\text {Ser612 }}$ and cleaved PARP (cPARP) levels were associated with decreased IRS-1 and phosphorylated Akt in ageing c$\mathrm{Kit} \beta \mathrm{Tg}$ mouse islets. (a) Western blot and densitometry analysis for total insulin receptor (IR) and phosphorylated IRS-1 ${ }^{\text {Ser612 }}$ levels in wild-type (WT) $(n=3)$ and c$\operatorname{Kit} \beta \operatorname{Tg}(n=4)$ mouse islets. (b) Representative images and quantification of IRS-1 (green) in insulin-positive (red) cells of ageing mice ( $n=4 \mathrm{WT}$ and $n=7 \mathrm{c}$ Kit $\beta$ Tg mouse pancreases/ group). Nuclei are stained with DAPI (blue). Scale bars, $50 \mu \mathrm{m}$. (c) Western blot and densitometry analysis of isolated islets for phosphorylated $\mathrm{Akt}^{\mathrm{Ser} 473}$ and ERK1/2 signals $(n=4$ isolated islets/group) and c-PARP levels ( $n=4 \mathrm{WT}$ and $n=3 \mathrm{c}-\mathrm{Kit} \beta \mathrm{Tg}$ mouse isolated islets/group). Data are normalised to loading protein or total (t-) protein levels in WT and c-Kit $\beta$ Tg mouse islets. (d, e) Phosphorylated Akt ${ }^{\text {Ser473 }}$ for WT (d) and c-Kit $\beta \mathrm{Tg}$ (e) mouse islets in response to stimulation with 2 $\mathrm{nmol} / 1$ insulin for $24 \mathrm{~h}$ of culture ( $n=4$ isolated islets/group). Data are expressed as mean \pm SEM. $* p<0.05$ (unpaired Student's $t$ test). Ins, insulin
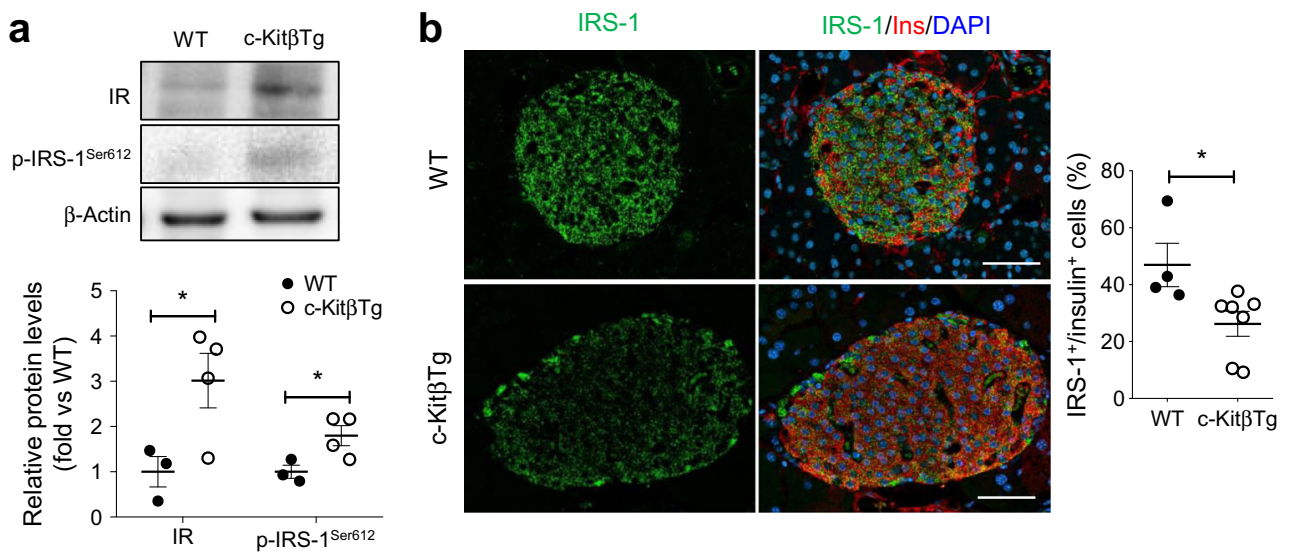

C
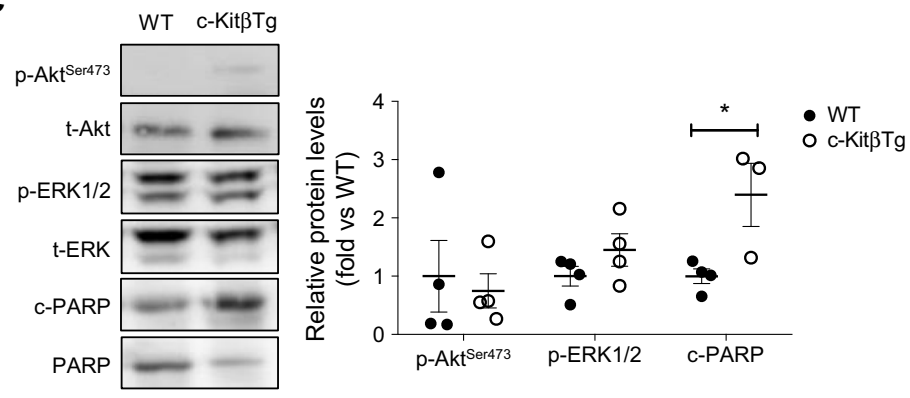

d
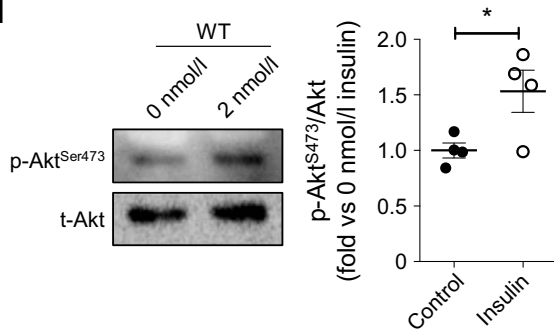

e
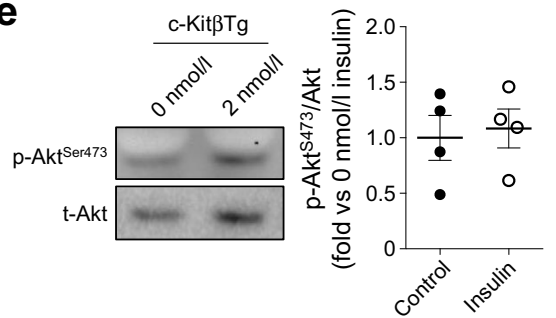

To determine an impairment of the insulin receptor-IRS-1 -Akt pathway in ageing c-Kit $\beta$ Tg mouse beta cells, isolated islets were treated with exogenous insulin at a concentration of $2 \mathrm{nmol} / \mathrm{l}$ for $24 \mathrm{~h}$. Protein analysis of the islet lysates revealed that islets from wild-type mice had increased levels of phosphorylated $\mathrm{Akt}^{\mathrm{Ser} 473}$ in response to insulin stimulation compared with untreated control islets (Fig. 4d). However, ageing c-Kit $\beta$ Tg mouse islets treated with 2 nmol/1 insulin showed no increase in $\mathrm{Akt}^{\mathrm{Ser} 473}$ phosphorylation when compared with untreated islets (Fig. 4e).

\section{Knockdown of insulin receptor on beta cells in ageing c-KitßTg mice protects against the development of glucose intolerance}

Since c-Kit $\beta$ Tg mouse islets developed impaired insulin receptor-IRS-1 signalling and a decreased response towards insulin stimulation, we crossed c-Kit $\beta$ Tg mice with the MIP- $\beta$ IRKO mouse line [19] to generate a model with temporally controlled tamoxifen-inducible loss of beta cell insulin receptor in c-Kit $\beta \mathrm{Tg}$ mice (c-Kit $\beta \mathrm{Tg} ; \beta$ IRKO) at 40 weeks of age. We elected to focus on control, c-Kit $\beta \mathrm{Tg}$ and c-Kit $\beta$ Tg; $\beta$ IRKO mouse groups (Figs 5, 6 and 7) and have included the ageing MIP- $\beta$ IRKO mice data in ESM Fig. 5.

Western blot and immunofluorescence analysis of insulin receptor deletion confirmed a $\sim 40 \%$ reduction in MIP- $\beta$ IRKO mouse islets (Fig. 5a,b). The body weight of ageing c-Kit $\beta \mathrm{Tg}$ and c-Kit $\beta$ Tg; $\beta$ IRKO mice at 60 weeks of age (20 weeks post-tamoxifen) was significantly increased over control littermates (Fig. 5c). High fasting blood glucose levels observed in ageing c-Kit $\beta \mathrm{Tg}$ mice were not displayed in ageing $\mathrm{c}$ Kit $\beta$ Tg; $\beta$ IRKO mice when compared with control mice (Fig. 5d). IPGTT in ageing c-Kit $\beta$ Tg; $\beta$ IRKO mice showed improved glucose tolerance when compared with c-Kit $\beta \mathrm{Tg}$ mice, although the difference was not statistically significant (Fig. 5e). Ageing MIP- $\beta$ IRKO mice showed similar body weight and blood glucose levels when compared with ageing 

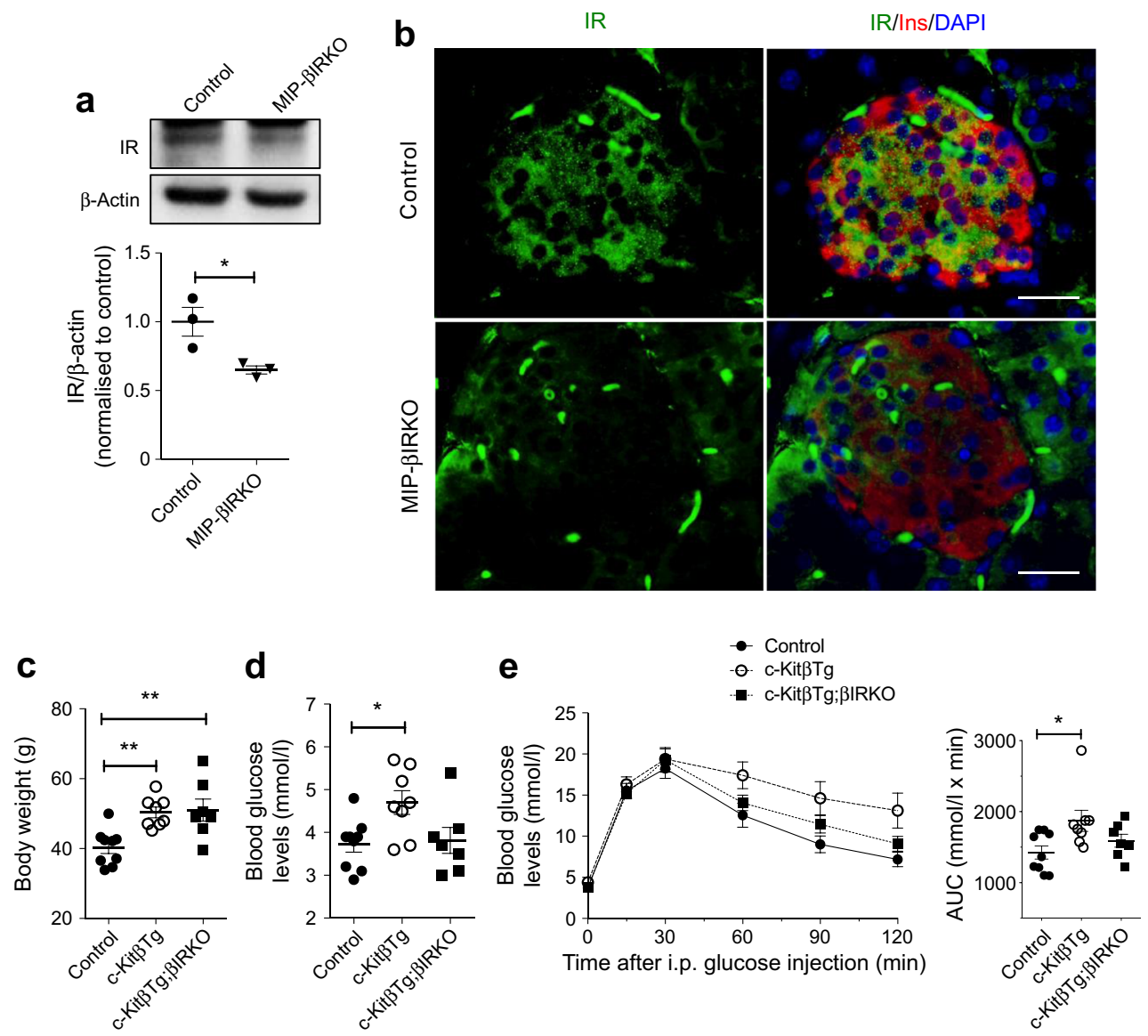

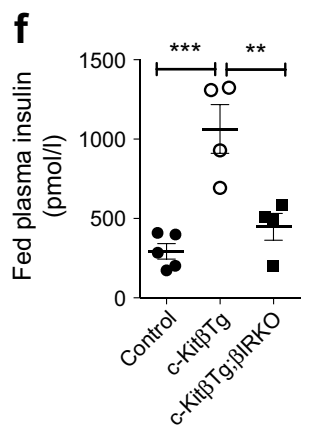

g

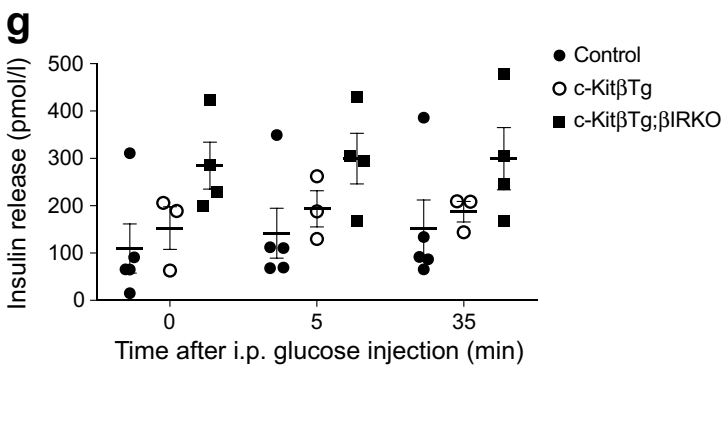

Fig. 5 c-Kit $\beta$ Tg; $\beta$ IRKO mice demonstrated improved glucose tolerance and insulin release at 60 weeks of age. (a) Western blot and densitometry analysis of insulin receptor (IR) in control and MIP- $\beta$ IRKO mouse islets after tamoxifen administration by oral gavage. MIP- $\beta$ IRKO mice were used to confirm tamoxifen efficiency for Cre-induced excision of floxed IR regions in $I R^{f l / f l}$ mice ( $n=3$ isolated islets/group). (b) Representative immunofluorescence images of control and MIP- $\beta$ IRKO mouse pancreases for IR (green) in insulin-positive cells (red). Nuclei are stained with DAPI (blue). Scale bars, $25 \mu \mathrm{m}$. (c, d) Fasting body weight (c) and blood glucose (d) at 20 weeks post-tamoxifen in control, c-Kit $\beta$ Tg and cKit $\beta$ Tg; $\beta$ IRKO mice aged 60 weeks $(n=9$ control, $n=8 \mathrm{c}-\mathrm{Kit} \beta \mathrm{Tg}$ and

control mice (ESM Fig. 5a,b) and while ageing MIP- $\beta$ IRKO mice had higher IPGTT glucose levels, the difference was not statistically significant when compared with the other ageing groups (ESM Fig. 5c). Cardiac plasma samples revealed that fed ageing c-Kit $\beta$ Tg mice had significantly elevated insulin $n=7$ c-Kit $\beta$ Tg; $\beta$ IRKO mice/group). (e) Blood glucose levels and corresponding AUC during IPGTT in ageing mice $(n=9$ control, $n=8 \mathrm{c}-\mathrm{Kit} \beta \mathrm{Tg}$ and $n=7 \mathrm{c}-\mathrm{Kit} \beta \mathrm{Tg} ; \beta \mathrm{IRKO}$ mice/group). (f) Fed plasma insulin in mice at the time of dissection ( $n=5$ control, $n=4 \mathrm{c}-\mathrm{Kit} \beta \mathrm{Tg}$ and $n=4 \mathrm{c}-$ Kit $\beta$ Tg; $\beta$ IRKO mice/group). (g) In vivo GSIS plasma insulin (pmol/l) at baseline ( $0 \mathrm{~min})$ and at $5 \mathrm{~min}$ and $35 \mathrm{~min}$ after glucose challenge $(n=5$ control, $n=3 \mathrm{c}-\mathrm{Kit} \beta \mathrm{Tg}$ and $n=4 \mathrm{c}-\mathrm{Kit} \beta \mathrm{Tg} ; \beta$ IRKO mice/group). Data are expressed as mean \pm SEM. $* p<0.05, * * p<0.01$ and $* * * p<0.001$ (Figure 5a, unpaired Student's $t$ test; Figures $5 \mathrm{c}-\mathrm{g}$, one-way ANOVA with Tukey's post hoc test). Ins, insulin

levels compared with control and c-Kit $\beta$ Tg; $\beta$ IRKO mice (Fig. 5f). In addition, ageing $\mathrm{c}-\mathrm{Kit} \beta \mathrm{Tg}$; $\beta \mathrm{IRKO}$ mice exposed to an in vivo GSIS test showed enhanced insulin release over c-Kit $\beta$ Tg mice, although the difference did not reach statistical significance (Fig. 5g and ESM Fig. 6). 

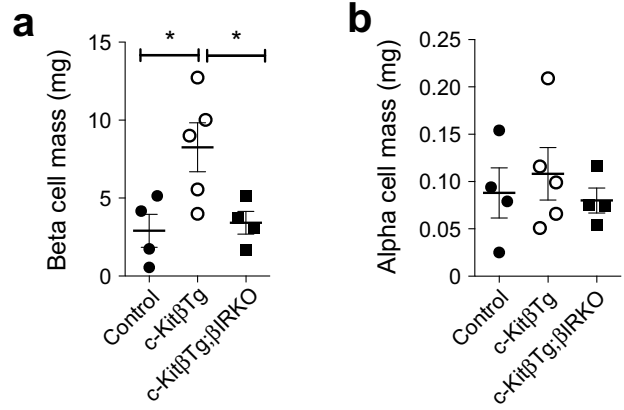

C
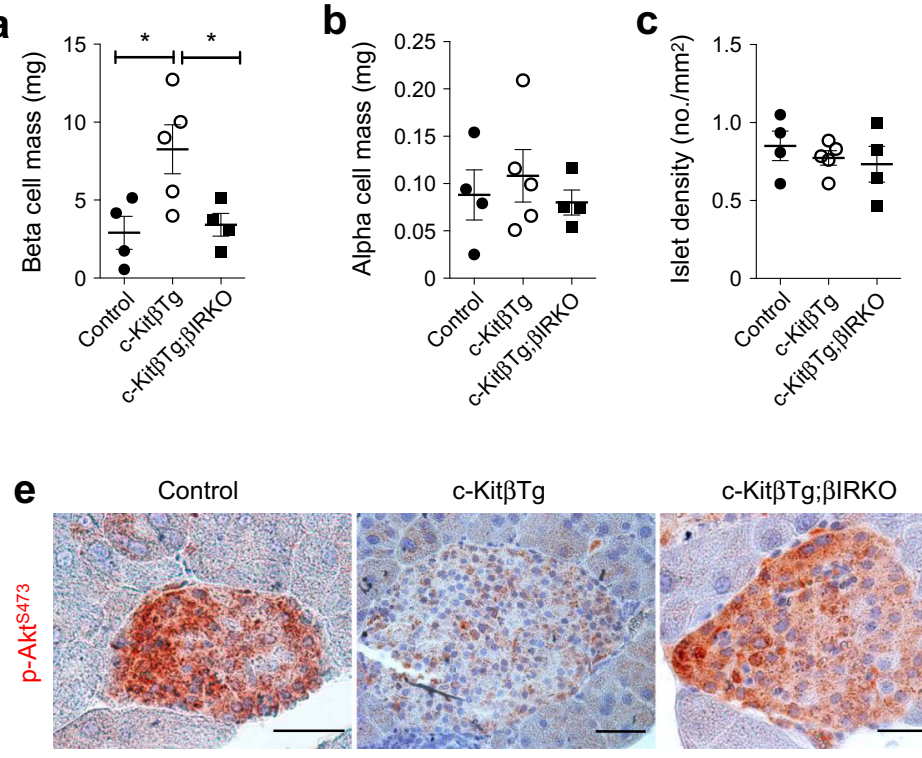

f
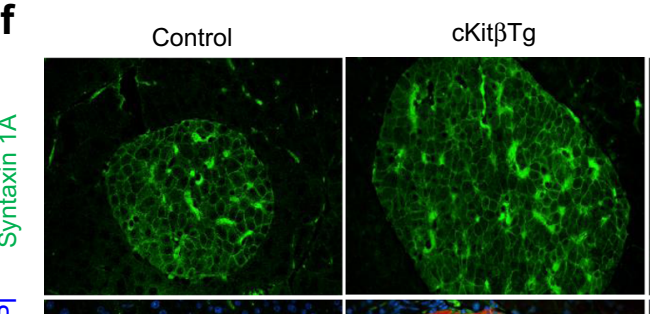

\section{cKit $\beta$ Tg; $\beta I R K O$}

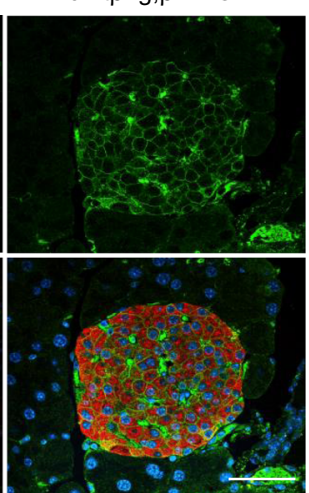

d
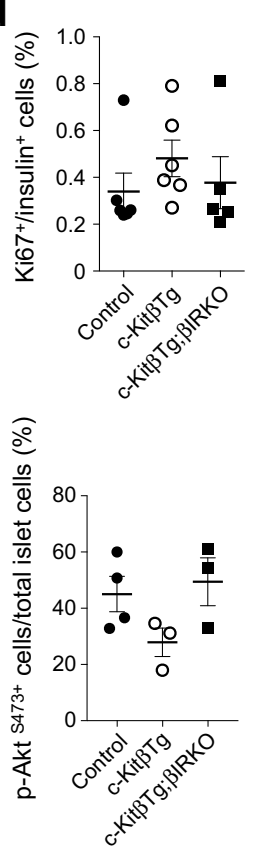

c-Kit $\beta$ Tg; $\beta I R K O$
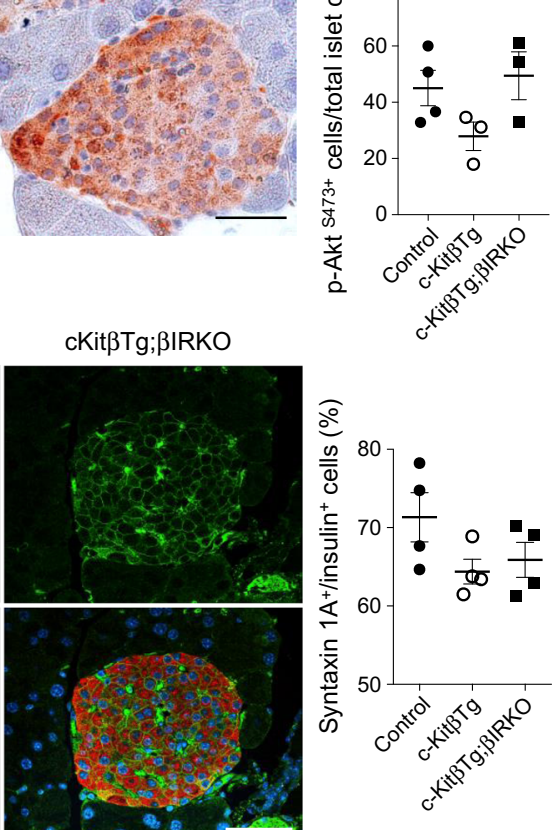

Fig. 6 Beta cell mass, proliferation, intracellular signalling and syntaxin $1 \mathrm{~A}$ expression in ageing c-Kit $\beta \mathrm{Tg}$; $\beta \mathrm{IRKO}$ mice. (a-c) Morphometric analysis for beta cell mass (a), alpha cell mass (b) and islet density (c) ( $n=4$ control, $n=5 \mathrm{c}-\mathrm{Kit} \beta \mathrm{Tg}$ and $n=4 \mathrm{c}-\mathrm{Kit} \beta \mathrm{Tg} ; \beta \mathrm{IRKO}$ mouse pancreases/group). (d) Beta cell proliferation measured using Ki67 staining in beta cells of ageing control, c-Kit $\beta$ Tg and c-Kit $\beta$ Tg; $\beta$ IRKO mice ( $n=6$ control, $n=6 \mathrm{c}-\mathrm{Kit} \beta \mathrm{Tg}$ and $n=5 \mathrm{c}-\mathrm{Kit} \beta \mathrm{Tg} ; \beta$ IRKO mouse pancreases/group). (e) Representative immunohistochemical images and quantification of phosphorylated $\mathrm{Akt}^{\mathrm{S} 473}$ (red) staining in ageing control,

Examination of islet morphology revealed that beta cell mass was decreased in c-Kit $\beta$ Tg; $\beta$ IRKO mice compared with ageing c-Kit $\beta$ Tg littermates (Fig. 6a). Alpha cell mass and islet density did not differ between control, c-Kit $\beta \mathrm{Tg}$ and cKit $\beta T g$; $\beta$ IRKO mice (Fig. 6b,c). Beta cell proliferation was higher in ageing c-Kit $\beta \mathrm{Tg}$ mice than in control and cKit $\beta$ Tg; $\beta$ IRKO mice but the difference did not reach statistical significance (Fig. 6d). Phosphorylated $\mathrm{Akt}^{\mathrm{Ser} 473}$ staining was reduced in islets from ageing c-Kit $\beta$ Tg mice compared with control and c-Kit $\beta$ Tg; $\beta$ IRKO mice, although this did not reach statistical significance (Fig. 6e). The percentage of syntaxin 1A-positive beta cells was similar between the three groups (Fig. 6f). Analysis of transcription factors revealed that
c-Kit $\beta$ Tg and c-Kit $\beta$ Tg; $\beta$ IRKO mouse islets ( $n=4$ control, $n=3 \mathrm{c}-\mathrm{Kit} \beta \mathrm{Tg}$ and $n=3 \mathrm{c}-\mathrm{Kit} \beta \mathrm{Tg} ; \beta$ IRKO mouse pancreases/group). Haematoxylin staining is purple. Scale bars, $50 \mu \mathrm{m}$. (f) Immunofluorescence images and quantification for the SNARE protein syntaxin 1A (green) in insulin-positive (red) cells of ageing (60 weeks) control, c-Kit $\beta$ Tg, and cKit $\beta$ Tg; $\beta$ IRKO mice ( $n=4$ mouse pancreases/group). Nuclei are stained with DAPI (blue). Scale bars, $50 \mu \mathrm{m}$. Data are expressed as mean $\pm \mathrm{SEM}$. ${ }^{*} p<0.05$ (one-way ANOVA with Tukey's post hoc test). Ins, insulin

nuclear PDX-1 expression was similar among the three ageing mouse groups (Fig. 7a). Nuclear FOXO1 in ageing c-Kit $\beta$ Tg mouse islets was increased in comparison with control mouse islets (Fig. 7b). FOXO1 nuclear localisation in c$\mathrm{Kit} \beta \mathrm{Tg} ; \beta$ IRKO islets was reduced when compared with ageing c-Kit $\beta$ Tg islets but the difference was not statistically significant. Interestingly, nuclear MafA levels were increased in ageing c-Kit $\beta$ Tg; $\beta$ IRKO mouse islets compared with both control and c-Kit $\beta$ Tg mice (Fig. 7c). These results demonstrate that reduced insulin receptor signalling in c-Kitoverexpressing beta cells affects beta cell mass during ageing and can partially rescue the detrimental effects seen in ageing c-Kit $\beta$ Tg mice. 
Fig. 7 Localisation of nuclear transcription factors in ageing cKit $\beta$ Tg; $\beta$ IRKO mice.

Representative double

immunofluorescence images and quantification for nuclear PDX-1 (a) $n=3$ control, $n=5$ c-Kit $\beta \mathrm{Tg}$ and $n=3 \mathrm{c}-\mathrm{Kit} \beta \mathrm{Tg}$; $\beta$ IRKO mouse pancreases/group), FOXO1 (b; $n=5$ control, $n=5 \mathrm{c}-\mathrm{Kit} \beta \mathrm{Tg}$ and $n=4 \mathrm{c}-\mathrm{Kit} \beta \mathrm{Tg} ; \beta$ IRKO mouse pancreases/group) and MafA (c; $n=4$ control, $n=4 \mathrm{c}-\mathrm{Kit} \beta \mathrm{Tg}$ and $n=3$ c-Kit $\beta$ Tg; $\beta$ IRKO mouse pancreases/group) (green) in insulin-positive (red) cells of ageing (60 weeks) control, cKit $\beta$ Tg and c-Kit $\beta$ Tg; $\beta$ IRKO mice. Nuclei are stained with DAPI (blue). Scale bars, $50 \mu \mathrm{m}$. Data are expressed as mean \pm SEM. * $p<0.05$ (one-way ANOVA with Tukey's post hoc test). Ins, insulin
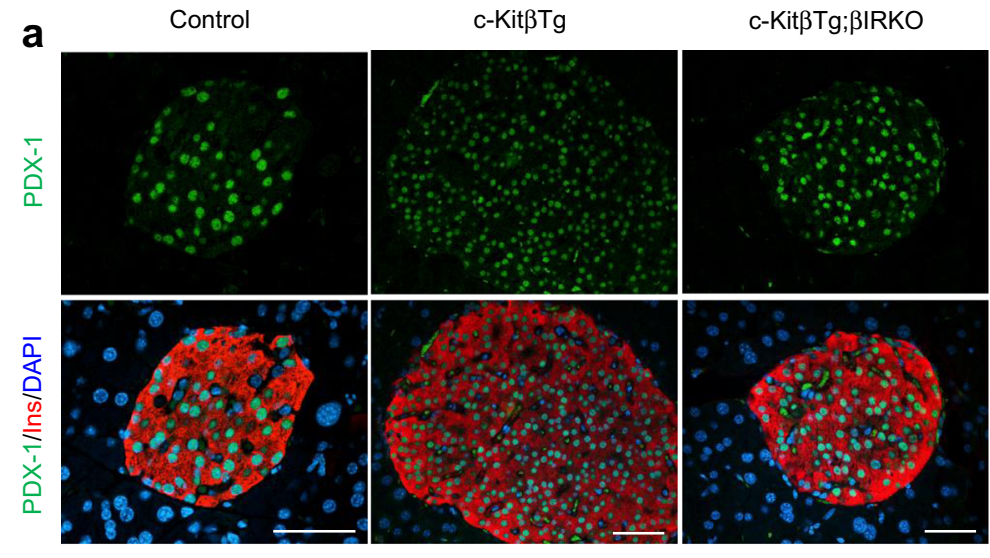

c-Kit $\beta$ Tg; $\beta I R K O$
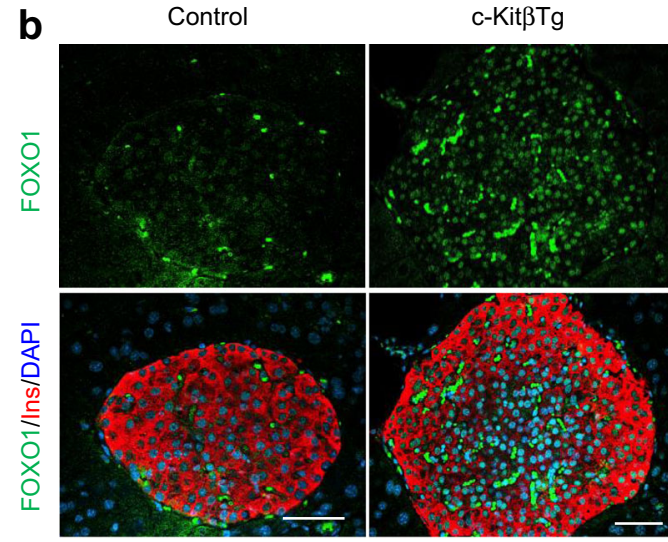

c-KitßTg; $\beta I R K O$
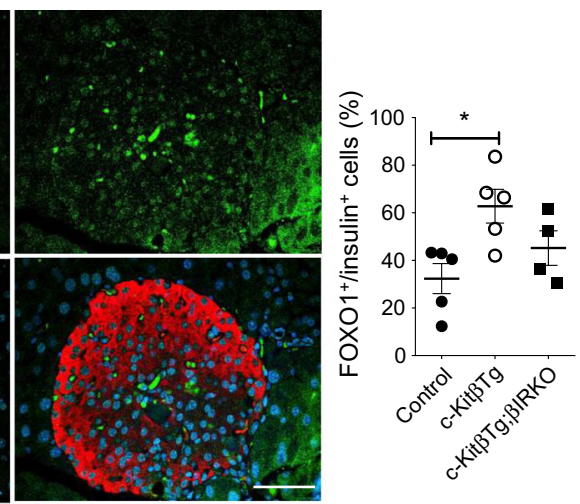

C

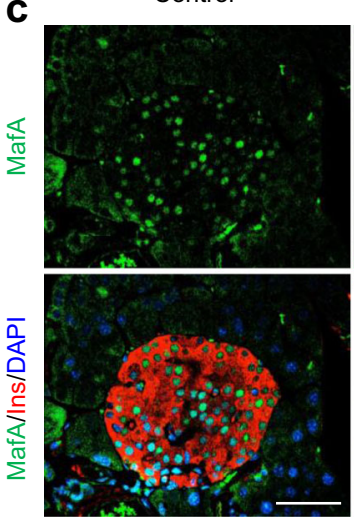

c-KitßTg

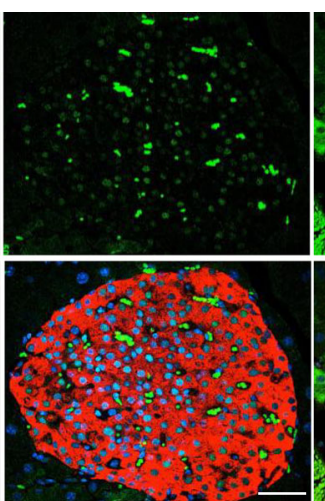

c-Kit $\beta$ Tg; $\beta I R K O$

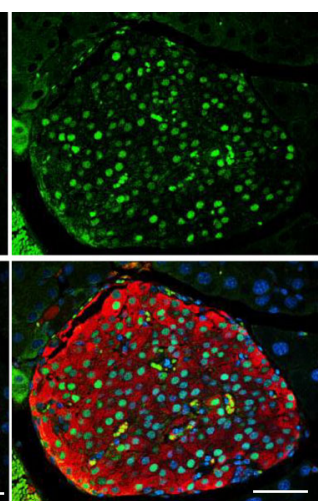

\section{Discussion}

The results presented in this paper characterise the longterm effects of chronic c-Kit receptor expression in murine beta cells. Ageing c-Kit $\beta$ Tg mice lose their capacity to regulate glucose levels due to reduced insulin secretion from beta cell. Beta cell mass and proliferation were maintained in c-Kit $\beta \mathrm{Tg}$ mice throughout ageing, yet increased apoptosis and decreased insulin exocytotic proteins were observed in ageing c-Kit $\beta$ Tg mouse beta cells. Ageing c-Kit $\beta$ Tg mouse islets displayed increased expression levels of insulin receptor and phosphorylated
IRS-1 ${ }^{\text {Ser612 }}$, resulting in negative feedback on the PI3KAkt pathway, enhanced nuclear shuttling of FOXO1 and decreased response to insulin stimulation in insulintreated ageing c-Kit $\beta$ Tg mouse islets (Fig. 8) [21]. The reduced beta cell insulin receptor expression in ageing cKit $\beta$ Tg; $\beta$ IRKO mice led to partially restored glucose tolerance through upregulation of MafA. This study demonstrates that prolonged overexpression of the c-Kit receptor, although able to improve glucose tolerance and insulin release in the short term, can induce beta cell dysfunction and insulin secretory defects through chronic activation of the insulin receptor-insulin signalling pathway. 


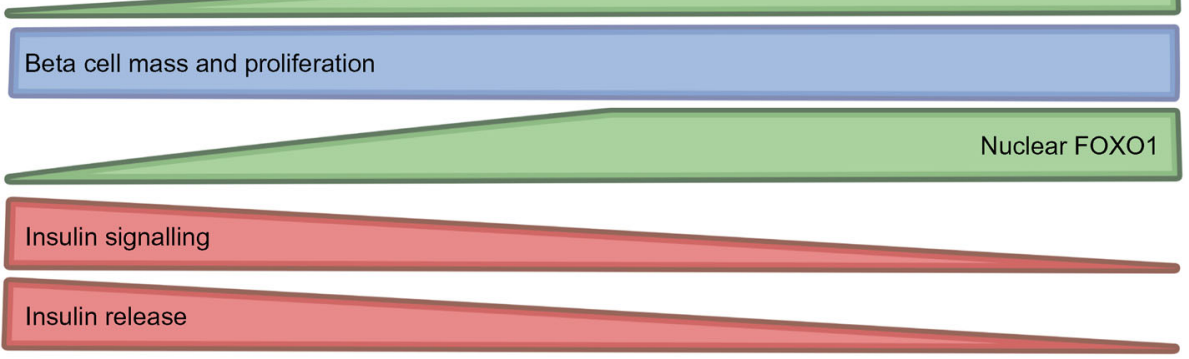

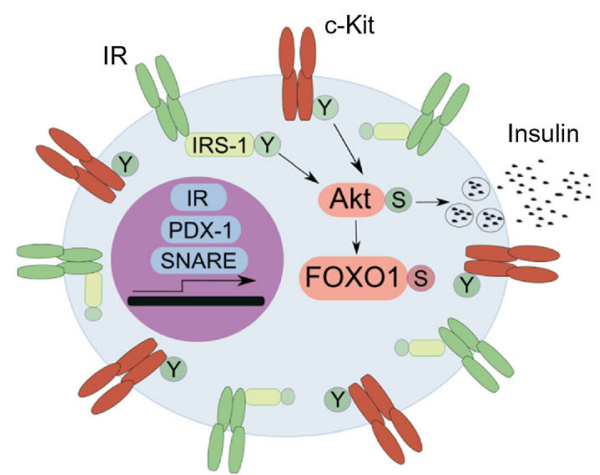

Young c-Kit $\beta T g$ beta cells

Fig. 8 Schematic for proposed model of the effects of chronic c-Kit overexpression on insulin secretion in ageing beta cells. Initial c-Kit activation, as seen in young c-Kit $\beta T$ g mice, leads to improved beta cell function and insulin secretion (black dots represent insulin molecules) through enhanced Akt signalling, nuclear localisation of PDX-1 and increased expression of insulin receptor (IR) and IRS [4]. When c-Kit overexpression is maintained throughout ageing, c-Kit $\beta \mathrm{Tg}$ mice develop a loss of glucose tolerance linked to the phosphorylation of IRS-1 ${ }^{\text {Ser612 }}$ through long-term c-Kit and IR signalling (red dashed arrows) [21] and

Previous studies established that c-Kit overexpression in 8week-old c-Kit $\beta \mathrm{Tg}$ mice results in improved insulin release under normal diet and short-term high-fat diet challenge [4]. The current study demonstrated that long-term beta cell c-Kit overexpression in ageing mice resulted in glucose intolerance due to reduced insulin release, which is similar to the dysfunction observed after long-term high-fat diet challenge in c-Kit $\beta T g$ mice [7]. Although beta cell proliferation has been reported to decrease in normal ageing models [11], the ageing c-Kit $\beta \mathrm{Tg}$ mice maintained their high beta cell proliferation rate and enlarged beta cell mass seen in the 8-week-old model. A notable finding in ageing c-Kit $\beta T$ g mice is the increased body weight seen at 60 weeks of age. The obesity seen in ageing c-Kit $\beta T g$ mice could account for the development of glucose intolerance in spite of enhanced beta cell mass and proliferation, which is a common phenotype observed in C57BL/6 mice fed a high-fat diet [22]. An intracellular signalling difference noted in ageing c-Kit $\beta T g$ mice was the lack of increased Akt phosphorylation seen in young c-Kit $\beta$ Tg mice [4] and a relative increase in ERK signalling. ERK phosphorylation has been shown to increase beta cell

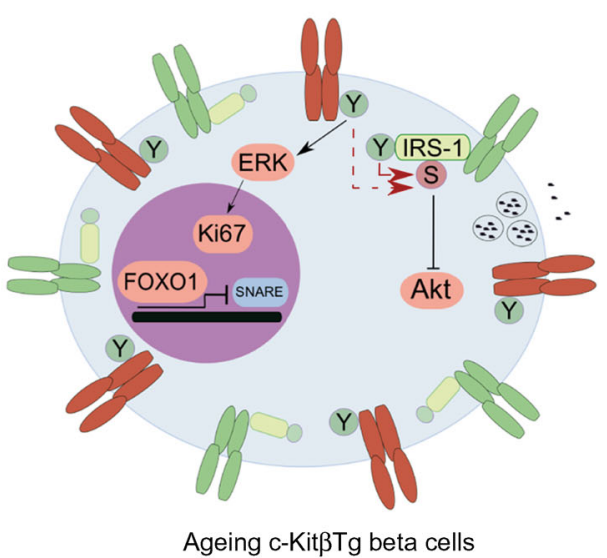

this results in a loss of Akt signalling. Nuclear shuttling of FOXO1 and insulin release defects are promoted due to reduced levels of SNARE proteins. This impairment of the IR-IRS-1-Akt pathway in ageing c$\mathrm{Kit} \beta \mathrm{Tg}$ mouse beta cells can be partially rescued by reducing the expression of beta cell IR in tandem with c-Kit overexpression, which restores insulin secretion and glucose tolerance. This figure was assembled using Inkscape software, version 0.92 (software can be downloaded at https:// inkscape.org/release/inkscape-0.92.4/). S, phosphorylated serine site; Y, phosphorylated tyrosine site

proliferation [23], and signalling 'rerouting' through the ERK pathway due to PI3K-C2 $\alpha$ knockdown is linked to increased proliferation in $o b / o b$ mouse islets [24]. Islet survival rate, which was decreased in ageing c-Kit $\beta$ Tg mice as indicated by increased levels of cleaved PARP and cleaved caspase 3, has also been shown to be dependent on maintained Akt signalling [25]. The percentage of apoptotic beta cells cultured in high glucose was increased when PI3K-Akt signalling was inhibited but was unchanged after ERK inhibition [26]. These findings from ageing c-Kit $\beta \mathrm{Tg}$ mice indicate that c-Kit activation under long-term metabolic stresses cause intracellular signalling changes that can impact islet survival rate and proliferation.

The altered expression of SNARE proteins within ageing cKit $\beta T g$ mouse islets contributed to decreased insulin release and glucose intolerance. The PI3K-Akt signalling pathway has been linked to regulation of SNARE levels within beta cells and has been shown to affect insulin secretion. Mice with a total loss of PI3K signalling ( $\beta$ DKO mice) have decreased mRNA and protein levels of exocytotic molecules, including syntaxin 1A, SNAP25 and VAMP2, and are restored upon 
introduction of constitutive Akt signalling [27]. Similar to ageing c-Kit $\beta$ Tg mice, $\beta$ DKO mice also show increased nuclear FOXO1 and ERK signalling [27]. Akt phosphorylation regulated the cytoplasmic sequestering of FOXO1 and transcription of $P d x-1$ in beta cells [28]. Reduced SNARE protein expression has been noted in $d b / d b$ mouse and $f a / f a$ rat models and in individuals with type 2 diabetes [29-31]. The high fed plasma insulin secretion and glucose intolerance in ageing cKit $\beta T$ g mice may reflect this defect, where loss of SNARE proteins due to reduced levels of phosphorylated Akt leads to FOXO1 nuclear localisation and dysfunctional insulin release.

Our previous study determined that young c-Kit $\beta T g$ mice (828 weeks of age) demonstrated increased insulin release and enhanced insulin receptor-IRS1/2-Akt ${ }^{\text {Ser473 }}$ signalling when compared with age-matched wild-type mice [4]. However, while ageing c-Kit $\beta T g$ mice displayed increased insulin receptor protein levels in islets, there was also a significant increase in IRS$1^{\text {Ser612 }}$ phosphorylation in the islets. Serine phosphorylation of IRS-1 has been shown to negatively feed back to the PI3K-Akt pathway, resulting in downregulation of its activity, promotion of degradation of the IRS-1 protein and insulin resistance [32, 33]. Maintenance of the insulin receptor-IRS signalling axis has also been implicated in glucose-induced FOXO1 nuclear exclusion and insulin resistant $o b / o b$ mouse islets demonstrated both increased nuclear FOXO1 expression along with reduced levels of SNARE proteins SNAP25 and VAMP2 [34, 35]. Inhibiting the Akt-mechanistic target of rapamycin kinase (mTOR) signalling axis prevents serine phosphorylation and prolongs tyrosine phosphorylation of IRS-1, leading to maintained IRS-1 signalling [33]. Insulin resistance has recently been implicated in the enhanced presence of beta cell ageing markers, as seen in mice with induced hyperinsulinaemia through the insulin receptor antagonist S961 [36]. The high fed plasma insulin levels found in ageing c-Kit $\beta$ Tg mice may indicate the development of beta cell insulin resistance and contribute to the dysfunction seen in ageing beta cells. Inhibiting the development of insulin resistance in islets by reducing their prolonged insulin receptor signalling, which was the aim of the insulin receptor knockdown in ageing c-Kit $\beta$ Tg; $\beta$ IRKO mice, can serve as a potential mechanism to alleviate the dysfunction that has occurred.

Knockdown of the insulin receptor in c-Kit $\beta T$ g mice aged 40 weeks partially restored glucose tolerance with ageing. This reduction in beta cell insulin signalling can be beneficial since prolonged circulating insulin has been shown to affect glucose tolerance and insulin sensitivity in mice $[37,38]$. The enhanced proliferation and reduced syntaxin $1 \mathrm{~A}$ protein expression found in ageing c-Kit $\beta$ Tg mice was not seen in the MIP-CreERcrossed ageing mouse model, where the cohort of ageing cKit $\beta$ Tg mice demonstrated only mild glucose intolerance and similar levels of Ki67-positive and syntaxin 1A-positive beta cell when compared with control and c-Kit $\beta$ Tg; $\beta$ IRKO mice. This may be due to confounding effects attributed to both the MIPCreER mouse model and the tamoxifen administration used in the second part of this study. The growth hormone minigene found within the MIP-CreER mouse model is transcribed and has been shown to produce increased beta cell mass and proliferation [39, 40], while tamoxifen can blunt beta cell proliferation when administered to mice [41]. Another limitation to consider is the incomplete insulin receptor knockdown achieved in ageing c-Kit $\beta$ Tg; $\beta$ IRKO mice administered tamoxifen at 40 weeks ( $\sim 40 \%$ reduction). Previous knockout mouse models from our laboratory that were crossed with the MIP-CreERT line achieved a $\sim 40-70 \%$ protein reduction in the floxed sequence $[19,42]$. One notable change is increased nuclear MafA levels observed in ageing c-Kit $\beta$ Tg; $\beta$ IRKO mice compared with control and cKit $\beta$ Tg mice. Nuclear FOXO1 can increase MafA expression under metabolic stresses, as seen in hyperglycaemia and high-fat diet feeding [43, 44], and MafA is required for insulin secretion [45-47]. This may indicate that nuclear FOXO1 expression in ageing c-Kit $\beta$ Tg mice develops initially as a response to metabolic stress but results in glucose intolerance due to reduced insulin signalling; reduction of insulin receptor expression in ageing c-Kit $\beta$ Tg; $\beta$ IRKO mice may delay the progression of glucose intolerance through MafA upregulation.

The present study demonstrates that long-term overexpression of c-Kit in beta cells does not maintain the improved glucose tolerance seen in mice with short-term c-Kit activation and results in altered beta cell function that reduces glucose-induced insulin exocytosis (Fig. 8). Examining the long-term activation of c-Kit in a mouse model has identified that transient signalling through the receptor can improve beta cell function and the expansion of the beta cell compartment, yet chronic activation of this pathway can result in the development of beta cell dysfunction that leads to compromised blood glucose control. The use of receptor tyrosine kinase-based therapies to enhance beta cell function in transplanted murine, primate and human islets has been previously studied [48, 49]. However, the long-term effects of chronic receptor tyrosine kinase signalling must be examined to determine their lasting efficacy and any potential complications. Regulating the duration of c-Kit overexpression to prevent the development of negative feedback in beta cells needs to be considered when examining the potential use of receptor tyrosine kinase-based therapies for the treatment of diabetes in order to ensure optimal beta cell function.

Acknowledgements Portions of the submitted manuscript were presented at the 53rd European Association for the Study of Diabetes (EASD) Annual Meeting in Lisbon, Portugal (12-15 Sept 2017).

Data availability The data analysed during this study are available from the corresponding author on reasonable request. The data points generated throughout this study are published in the main text and ESM Figures.

Funding This project was supported by a grant from the Canadian Institute of Health Research.

Duality of interest The authors declare that there is no duality of interest associated with this manuscript. 
Contribution statement $\mathrm{AO}$ and ZCF contributed to the acquisition of data, interpretation of results and preparation and revision of the manuscript and gave final approval for the version to be published. JL contributed to the acquisition and interpretation of data and manuscript drafting and revision and gave final approval for the version to be published. JS contributed to histological analysis of sections and interpretation of data and manuscript drafting and gave final approval for the version to be published. SPY contributed to development of the mouse lines used in this study, critical comments for manuscript and revision preparation and gave final approval for the version to be published. RW contributed to the experimental design, interpretation of data, manuscript preparation and revision and gave final approval for the version to be published. RW is the guarantor of this work.

\section{References}

1. Rachdi L, El Ghazi L, Bernex F, Panthier JJ, Czernichow P, Scharfmann R (2001) Expression of the receptor tyrosine kinase $\mathrm{KIT}$ in mature $\beta$-cells and in the pancreas in development. Diabetes 50(9):2021-2028. https://doi.org/10.2337/diabetes.50.9.2021

2. Peters K, Panienka R, Li J, Klöppel G, Wang R (2005) Expression of stem cell markers and transcription factors during the remodeling of the rat pancreas after duct ligation. Virchows Arch 446(1):56-63. https://doi.org/10.1007/s00428-004-1145-7

3. Li J, Quirt J, Do HQ et al (2007) Expression of c-Kit receptor tyrosine kinase and effect on beta-cell development in the human fetal pancreas. Am J Physiol Endocrinol Metab 293(2):E475-E483. https://doi.org/10.1152/ajpendo.00172.2007

4. Feng ZC, Li J, Turco BA, Riopel M, Yee SP, Wang R (2012) Critical role of c-Kit in beta cell function: increased insulin secretion and protection against diabetes in a mouse model. Diabetologia 55(8):2214-2225. https://doi.org/10.1007/s00125-012-2566-5

5. Feng ZC, Donnelly L, Li J, Krishnamurthy M, Riopel M, Wang R (2012) Inhibition of Gsk $3 \beta$ activity improves $\beta$-cell function in $c$ $\mathrm{Kit}^{\mathrm{Wv} /+}$ male mice. Lab Investig 92(4):543-555. https://doi.org/10. 1038/labinvest.2011.200

6. Krishnamurthy M, Ayazi F, Li J et al (2007) c-Kit in early onset of diabetes: a morphological and functional analysis of pancreatic $\beta$ cells in c-KitW-v mutant mice. Endocrinology 148(11):5520-5530. https://doi.org/10.1210/en.2007-0387

7. Feng ZC, Popell A, Li J et al (2015) c-Kit receptor signaling regulates islet vasculature, $\beta$-cell survival, and function in vivo. Diabetes 64(11):3852-3866. https://doi.org/10.2337/db15-0054

8. Feng ZC, Riopel M, Li J, Donnelly L, Wang R (2013) Downregulation of Fas activity rescues early onset of diabetes in c-Kit $^{\mathrm{Wv} /+}$ mice. Am J Physiol Endocrinol Metab 304(6):E557E565. https://doi.org/10.1152/ajpendo.00453.2012

9. Perfetti R, Rafizadeh CM, Liotta AS, Egan JM (1995) Agedependent reduction in insulin secretion and insulin mRNA in isolated islets from rats. Am J Phys 269(6 Pt 1):E983-E990

10. Perfetti R, Wang Y, Shuldiner AR, Egan JM (1996) Molecular investigation of age-related changes in mouse endocrine pancreas. J Gerontol A Biol Sci Med Sci 51(5):B331-B336

11. Teta M, Long SY, Wartschow LM, Rankin MM, Kushner JA (2005) Very slow turnover of $\beta$-cells in aged adult mice. Diabetes 54(9): 2557-2567. https://doi.org/10.2337/diabetes.54.9.2557

12. Tschen SI, Dhawan S, Gurlo T, Bhushan A (2009) Age-dependent decline in $\beta$-cell proliferation restricts the capacity of $\beta$-cell regeneration in mice. Diabetes 58(6):1312-1320. https://doi.org/10. 2337/db08-1651
13. Rankin MM, Kushner JA (2009) Adaptive $\beta$-cell proliferation is severely restricted with advanced age. Diabetes 58(6):1365-1372. https://doi.org/10.2337/db08-1198

14. Zeng N, Yang KT, Bayan JA et al (2013) PTEN controls $\beta$-cell regeneration in aged mice by regulating cell cycle inhibitor $\mathrm{p} 16^{\text {ink } 4 \mathrm{a}}$ Aging Cell 12(6):1000-1011. https://doi.org/10.1111/acel.12132

15. Stolovich-Rain M, Hija A, Grimsby J, Glaser B, Dor Y (2012) Pancreatic beta cells in very old mice retain capacity for compensatory proliferation. J Biol Chem 287(33):27407-27414. https:// doi.org/10.1074/jbc.M112.350736

16. Krishnamurthy J, Ramsey MR, Ligon KL et al (2006) $\mathrm{p} 16^{\mathrm{INK} 4 \mathrm{a}}$ induces an age-dependent decline in islet regenerative potential. Nature 443(7110):453-457. https://doi.org/10.1038/nature05092

17. Maedler K, Schumann DM, Schulthess F et al (2006) Aging correlates with decreased $\beta$-cell proliferative capacity and enhanced sensitivity to apoptosis: a potential role for Fas and pancreatic duodenal homeobox-1. Diabetes 55(9):2455-2462. https://doi.org/10.2337/ db05-1586

18. Helman A, Klochendler A, Azazmeh N et al (2016) p16 ${ }^{\text {Ink4a }}$-induced senescence of pancreatic beta cells enhances insulin secretion. Nat Med 22(4):412-420. https://doi.org/10.1038/nm.4054

19. Trinder M, Zhou L, Oakie A, Riopel M, Wang R (2016) $\beta$-Cell insulin receptor deficiency during in utero development induces an islet compensatory overgrowth response. Oncotarget 7(29):4492744940. https://doi.org/10.18632/oncotarget.10342

20. Furuyama K, Kawaguchi Y, Akiyama H et al (2011) Continuous cell supply from a Sox9-expressing progenitor zone in adult liver, exocrine pancreas and intestine. Nat Genet 43(1):34-41. https://doi. org/10.1038/ng. 722

21. Oakie A, Wang R (2018) $\beta$-Cell Receptor tyrosine kinases in controlling insulin secretion and exocytotic machinery: c-kit and insulin receptor. Endocrinology 159(11):3813-3821. https://doi.org/10. 1210/en.2018-00716

22. Peyot ML, Pepin E, Lamontagne J et al (2010) $\beta$-Cell failure in diet-induced obese mice stratified according to body weight gain: secretory dysfunction and altered islet lipid metabolism without steatosis or reduced $\beta$-cell mass. Diabetes 59(9):2178-2187. https://doi.org/10.2337/db09-1452

23. Beith JL, Alejandro EU, Johnson JD (2008) Insulin stimulates primary $\beta$-cell proliferation via Raf-1 kinase. Endocrinology 149(5): 2251-2260. https://doi.org/10.1210/en.2007-1557

24. Leibiger B, Moede T, Paschen M et al (2015) PI3K-C2 $\alpha$ knockdown results in rerouting of insulin signaling and pancreatic beta cell proliferation. Cell Rep 13(1):15-22. https://doi.org/10.1016/j. celrep.2015.08.058

25. Aikin R, Hanley S, Maysinger D et al (2006) Autocrine insulin action activates Akt and increases survival of isolated human islets. Diabetologia 49(12):2900-2909. https://doi.org/10.1007/s00125006-0476-0

26. Srinivasan S, Bernal-Mizrachi E, Ohsugi M, Permutt MA (2002) Glucose promotes pancreatic islet $\beta$-cell survival through a PI 3 kinase/Akt-signaling pathway. Am J Physiol Endocrinol Metab 283(4):E784-E793. https://doi.org/10.1152/ajpendo.00177.2002

27. Kaneko K, Ueki K, Takahashi N et al (2010) Class IA phosphatidylinositol 3-kinase in pancreatic $\beta$ cells controls insulin secretion by multiple mechanisms. Cell Metab 12(6):619-632. https://doi.org/10.1016/j.cmet.2010.11.005

28. Meur G, Qian Q, da Silva Xavier G et al (2011) Nucleo-cytosolic shuttling of FoxO1 directly regulates mouse Ins 2 but not Ins 1 gene expression in pancreatic beta cells (MIN6). J Biol Chem 286(15): 13647-13656. https://doi.org/10.1074/jbc.M110.204248

29. Andersson SA, Olsson AH, Esguerra JL et al (2012) Reduced insulin secretion correlates with decreased expression of exocytotic genes in pancreatic islets from patients with type 2 diabetes. Mol Cell Endocrinol 364(1-2):36-45. https://doi.org/10.1016/j.mce. 2012.08.009 
30. Do OH, Low JT, Gaisano HY, Thorn P (2014) The secretory deficit in islets from $d b / d b$ mice is mainly due to a loss of responding beta cells. Diabetologia 57(7):1400-1409. https://doi.org/10.1007/ s00125-014-3226-8

31. Chan CB, MacPhail RM, Sheu L, Wheeler MB, Gaisano HY (1999) $\beta$-cell hypertrophy in fa/fa rats is associated with basal glucose hypersensitivity and reduced SNARE protein expression. Diabetes 48(5):997-1005. https://doi.org/10.2337/diabetes.48.5. 997

32. Ueno M, Carvalheira JB, Tambascia RC et al (2005) Regulation of insulin signalling by hyperinsulinaemia: role of IRS-1/2 serine phosphorylation and the mTOR/p70 S6K pathway. Diabetologia 48(3):506-518. https://doi.org/10.1007/s00125-004-1662-6

33. Pederson TM, Kramer DL, Rondinone CM (2001) Serine/threonine phosphorylation of IRS-1 triggers its degradation: possible regulation by tyrosine phosphorylation. Diabetes 50(1):24-31. https://doi. org/10.2337/diabetes.50.1.24

34. Martinez SC, Cras-Méneur C, Bernal-Mizrachi E, Permutt MA (2006) Glucose regulates Foxo1 through insulin receptor signaling in the pancreatic islet $\beta$-cell. Diabetes 55(6):1581-1591. https://doi. org $/ 10.2337 / \mathrm{db} 05-0678$

35. Åvall K, Ali Y, Leibiger IB et al (2015) Apolipoprotein CIII links islet insulin resistance to $\beta$-cell failure in diabetes. Proc Natl Acad Sci U S A 112(20):E2611-E2619. https://doi.org/10.1073/pnas. 1423849112

36. Aguayo-Mazzucato C, van Haaren M, Mruk M et al (2017) $\beta$ Cell aging markers have heterogeneous distribution and are induced by insulin resistance. Cell Metab 25(4):898-910.e895. https://doi.org/ 10.1016/j.cmet.2017.03.015

37. Abdul-Hay SO, Kang D, McBride M, Li L, Zhao J, Leissring MA (2011) Deletion of insulin-degrading enzyme elicits antipodal, agedependent effects on glucose and insulin tolerance. PLoS One 6(6): e20818. https://doi.org/10.1371/journal.pone.0020818

38. Templeman NM, Flibotte S, Chik JHL et al (2017) Reduced circulating insulin enhances insulin sensitivity in old mice and extends lifespan. Cell Rep 20(2):451-463. https://doi.org/10.1016/j.celrep. 2017.06.048

39. Brouwers B, de Faudeur G, Osipovich AB et al (2014) Impaired islet function in commonly used transgenic mouse lines due to human growth hormone minigene expression. Cell Metab 20(6): 979-990. https://doi.org/10.1016/j.cmet.2014.11.004

40. Baan M, Kibbe CR, Bushkofsky JR, Harris TW, Sherman DS, Davis DB (2015) Transgenic expression of the human growth hormone minigene promotes pancreatic $\beta$-cell proliferation. Am J
Physiol Regul Integr Comp Physiol 309(7):R788-R794. https:// doi.org/10.1152/ajpregu.00244.2015

41. Carboneau BA, Le TD, Dunn JC, Gannon M (2016) Unexpected effects of the MIP-CreER transgene and tamoxifen on $\beta$-cell growth in C57B16/J male mice. Physiol Rep 4(18):e12863. https://doi.org/10.14814/phy2.12863

42. Peart J, Li J, Lee H, Riopel M, Feng ZC, Wang R (2017) Critical role of $\beta 1$ integrin in postnatal beta-cell function and expansion. Oncotarget 8(38):62939-62952. https://doi.org/10.18632/ oncotarget. 17969

43. Zhang T, Kim DH, Xiao X et al (2016) FoxO1 plays an important role in regulating $\beta$-cell compensation for insulin resistance in male mice. Endocrinology 157(3):1055-1070. https://doi.org/10.1210/ en.2015-1852

44. Kitamura YI, Kitamura T, Kruse JP et al (2005) FoxO1 protects against pancreatic beta cell failure through NeuroD and MafA induction. Cell Metab 2(3):153-163. https://doi.org/10.1016/j.cmet. 2005.08.004

45. Hang Y, Yamamoto T, Benninger RK et al (2014) The MafA transcription factor becomes essential to islet $\beta$-cells soon after birth. Diabetes 63(6): 1994-2005. https://doi.org/10.2337/db13-1001

46. Wang H, Brun T, Kataoka K, Sharma AJ, Wollheim CB (2007) MAFA controls genes implicated in insulin biosynthesis and secretion. Diabetologia 50(2):348-358. https://doi.org/10.1007/s00125006-0490-2

47. Zhang C, Moriguchi T, Kajihara M et al (2005) MafA is a key regulator of glucose-stimulated insulin secretion. Mol Cell Biol 25(12):4969-4976. https://doi.org/10.1128/MCB.25.12.49694976.2005

48. Staels W, Verdonck Y, Heremans Y et al (2018) Vegf-A mRNA transfection as a novel approach to improve mouse and human islet graft revascularisation. Diabetologia 61(8):1804-1810. https://doi. org/10.1007/s00125-018-4646-7

49. Fiaschi-Taesch NM, Berman DM, Sicari BM et al (2008) Hepatocyte growth factor enhances engraftment and function of nonhuman primate islets. Diabetes 57(10):2745-2754. https://doi. org/10.2337/db08-1085

Publisher's note Springer Nature remains neutral with regard to jurisdictional claims in published maps and institutional affiliations. 